Canadian Science Publishing

Biochemistry and Cell Biology Biochimie et biologie cellulaire

\title{
Proteomics Analysis of Latex from Hevea brasiliensis (Clone RRIM 600)
}

\begin{tabular}{|r|l|}
\hline Journal: & Biochemistry and Cell Biology \\
\hline Manuscript ID & bcb-2016-0144.R1 \\
\hline Manuscript Type: & Article \\
\hline Date Submitted by the Author: & 24-Aug-2016 \\
\hline Complete List of Authors: & $\begin{array}{l}\text { Habib, Mohd Afiq Hazlami; Universiti Sains Malaysia, Analytical } \\
\text { Biochemistry Research Centre } \\
\text { Gan, Chee Yuen; Universiti Sains Malaysia, Analytical Biochemistry } \\
\text { Research Centre } \\
\text { Othman, Fazilah; Anti-Doping Lab Qatar } \\
\text { Zainudin, Nurul Nabilah; Universiti Sains Malaysia, Analytical Biochemistry } \\
\text { Research Centre } \\
\text { Abdul Latiff, Aishah; Anti-Doping Lab Qatar } \\
\text { ISMAIL, MOHD NAZRI; Universiti Sains Malaysia, Analytical Biochemistry } \\
\text { Research Centre }\end{array}$ \\
\hline Keyword: & $\begin{array}{l}\text { Hevea brasiliensis, Rubber latex, Plant proteomics, Mass spectrometry, } \\
\text { Biosynthetic pathways }\end{array}$ \\
\hline
\end{tabular}




\section{Proteomics Analysis of Latex from Hevea brasiliensis (Clone RRIM 600)}

2 Mohd Afiq Hazlami Habiba, Gan Chee Yuen ${ }^{\mathrm{a}}$, Fazilah Othman ${ }^{\mathrm{b}}$, Nurul Nabilah Zainudin ${ }^{\mathrm{a}}$,

3 Aishah Abdul Latiff ${ }^{b} \&$ Mohd Nazri Ismail ${ }^{\text {a,* }}$

$4{ }^{a}$ Analytical Biochemistry Research Centre, Universiti Sains Malaysia, 11800 USM, Pulau

5 Pinang, Malaysia.

$6 \quad{ }^{\mathrm{b}}$ Anti-Doping Lab Qatar, Sports City St, Doha, Qatar

$7 \quad *$ Corresponding author

8 Dr. Mohd Nazri Ismail

9 Analytical Biochemistry Research Centre,

10 Universiti Sains Malaysia,

1111800 USM, Pulau Pinang, Malaysia.

$12+604-6532694 / 4694$

mdnazri@usm.my

\section{Abstract}

15 The natural rubber latex extracted from the bark of Hevea brasiliensis plays various important 16 roles in today's modern society. Following ultracentrifugation, the latex can be separated into 3 17 layers; C-serum, lutoids, and rubber particle. Previous studies showed that a large number of 18 proteins were present inside these three layers. However, a complete proteome for this important plant is still unavailable. Protein sequences have been recently translated from the completed draft genome database of $H$. brasiliensis leading to the creation of annotated protein databases of H. brasiliensis biosynthetic pathways; photosynthesis, latex allergens, rubberwood formation, latex biosynthesis, and disease resistance. This research was conducted to identify the proteins contained within the latex by way of de novo sequencing from mass spectric data obtained from the 3 layers of the latex. Peptides from these proteins were fragmented using collision-induced dissociation (CID), higher-energy collisional dissociation (HCD) and electron-transfer dissociation (ETD) activation methods. A large percentage of proteins from the biosynthetic pathways were successfully identified, ranging from $63 \%$ to $100 \%$. In addition, a total of 1839 unique proteins were identified from the whole translated draft genome database (AnnHBM). 
Keywords: Hevea brasiliensis; Rubber latex; Plant proteomics; Mass spectrometry; Biosynthetic pathways

\section{Introduction}

Rubber latex is a living cytoplasm from laticifer cells located in the secondary phloem of Hevea brasiliensis rubber trees. This latex is formed and stored in the rings of anastomosing laticifers in the inner bark. It consists of three major subcellular fractions in which the rubber particles, Cserum and lutoids are dispersing in an aqueous phase of the cytosol (Moir, 1959; Dickenson, 1969). These three subcellular fractions contain variety of proteins that are responsible for latex biosynthesis, defensive system and other biological pathways.

For example, rubber particles are the colloidal components that are naturally present in latex in which comprising $30-40 \%$ of the whole latex volume (Southorn and Yip, 1968; Gomez and Hamzah, 1989). The particles have homogenous and spherical rubber cores enveloped with a layer of membrane (Moir, 1959; Yeamg et al., 2002; Wu et al., 2008). The size of the particles varies from 0.02 to $3 \mathrm{~lm}$ and has been distinguished into three different Moir's zone according to sizes (Southorn, 1969; Yeang et al., 1995; Hamzah and Gomez, 1982; Dickenson, 1969). Two different major proteins have been identified in rubber particles at molecular masses of 14.6 and $24 \mathrm{kDa}$. These proteins were classified as proteolipids (Hasma, 1987; Wititsuwannakul et al., 2004) and were identified as latex allergens (i.e. Hev b1 and Hev b3) (Czuppon et al., 1993; Alenius et al., 1993; Yeang et al., 1996). The latter has been proposed to be tightly associated with small rubber particle and also involved in the biosynthesis of rubber (Oh et al., 1999). Lectin-like protein was also found in the recent years that are responsible for latex coagulation and mediating rubber particle aggregation.

The aqueous phase of laticiferous cytoplasmic, C-serum, is metabolically active. This fraction contains about $60 \%$ of whole latex proteins. Tata and Edwin (1970) showed a large number of proteins in gel electrophoresis analysis. $\alpha$-globulin is the highest abundant protein that contributes to the colloidal stability of the latex and rubber particles (Archer et al., 1963; Archer and Cockbain, 1955). Apart from that, several glycolytic enzymes and other common cytosolic enzymes were found in $\mathrm{C}$-serum in which they are actively involved in different metabolic processes (d'Auzac and Jacob, 1969; Wititsuwannakul et al., 1990; Suvachitanont and 
Wititsuwannakul, 1995; Koyama et al., 1996). For instances, calmodulin (a heat stable calcium binding protein) was found to be responsible for regulating different interrelated metabolic processes (Tangpakdee et al., 1997). It also has been shown to have the ability to activate HMGCoA reductase in lutoid or membrane fraction (Wititsuwannakul et al., 1990). In addition, several allergens (i.e. Hev b5, Hev b7, Hev b8 and Hev b9) were also identified.

Lutoids, the bottom layers after ultracentrifugation, play important roles in latex coagulation and protect the tree from exterior invasion (Wei et al., 2008; Kongsawadworakul et al., 2009). They are vacuolar organelles that contain a number of pathogenesis-related proteins that obtain antifungal properties (Stintzi et al., 1993). Research showed that hevein is the major protein (approximately 50\%) of lutoid body. It is formed via a proteolytic process from a precursor protein $(19 \mathrm{kDa})$ into a domain $(5 \mathrm{kDa})$ and a C-terminally located protein $(14 \mathrm{kDa})$ in which resulted in a ragged structure after the removal of residues at the $\mathrm{C}$-terminus of hevein (Soedjanaatmadja et al., 1994). Second and third major proteins, hevamine and $\beta$-1,3-glucanase, with molecular mass of $29 \mathrm{kDa}$ and $32-35 \mathrm{kDa}$, respectively, were also identified (Breton et al., 1995; Churngchow et al., 1995; Subroto et al., 1996; Sunderasan et al., 1995). The cDNA sequences of these proteins were determined and they were found to be post-translationally modified via removal of an $\mathrm{N}$-terminal signal peptide and a vacuolar targeting sequence from the C-terminus (Bokma et al., 2001; Chye et al., 1995). Other proteins such as osmotin-like protein (25 $\mathrm{kDa}$, antifungal protein) and citrate-binding protein (responsible for citrate accumulation in lutoids) were also found.

Until present, research works that have been performed resulted in very limited number of proteins identified. A proteome analysis on the rubber particles of $H$. brasiliensis has revealed 186 proteins, ranging from 3.9-194.2 kDa in molecular mass (Dai L. J. et al., 2013). A study on the different subcellular fractions of the latex proteome has also been conducted on the rubber producing plant Taraxacum brevicorniculatum which reveals that the proteins involved in rubber biosynthesis were distributed among the fractions (Wahler D. et al., 2012). Information on the post-translational modifications (PTM) is even more limited. Therefore, it was suggested to have a new strategy in order to identify as much protein as possible to better understand the various biological pathways in rubber latex. In our collaborative research works, we have used a 
genomic approach to identify the proteins in the rubber latex. Databases of these proteins in different pathways were also established, namely the photosynthesis, latex allergens, rubberwood formation, latex biosynthesis, and disease resistance. The details in each pathway of other databases were discussed in details in a previous work (Rahman et al., 2013). Therefore, using proteomic approach to search the expressed proteins in the fresh rubber latex would validate the results of the genome analysis. An efficient strategy with good quality of data is essential for the study in order to obtain the promising results.

The main objective of this study was to use proteomics to validate the result of the genomic analysis from the previous work (Rahman et al., 2013), so the results and discussions of this article will heavily depends on their work. In order to detect both the high and low abundant proteins, the activation protocols collision-induced dissociation (CID), high-energy collision dissociation (HCD) and electron-transfer dissociation (ETD) were used instead of just one activation protocol to generate characteristic fragments in the MS/MS experiment which ultimately establish amino acid sequences. In addition, we also employed a mass spectrometry method developed by Julian Saba and colleagues that uses HCD and ETD techniques to detect the low abundant glycoproteins (Saba et al., 2012). An Orbitrap mass spectrometer that has the capabilities to perform CID, HCD and ETD analyses coupled with a nano liquid chromatography was utilized and massive identification of protein in each subcellular fraction was then

performed using PEAKS Studio V6 (PEAKS). Hence, this approach would assist in understanding the pathways in different phases of the biological cycle.

\section{Methodology}

\subsection{Latex collection}

Rubber tree (H. Brasiliensis, Clone: RRIM600) grown in Baling, Kedah, Malaysia was tapped in the early morning. The fresh latex was collected in a plasticware and immediately froze in liquid nitrogen. The latex sample was stored in liquid nitrogen while it was sent to the laboratory.

\subsection{Protein extraction and purification}

The extraction of protein from the rubber latex was performed according to Wang et al. (2010) with slight modifications. The fresh latex was thawed and ultracentrifuged for 30 mins at 40,000 
$122 \mathrm{~g}$ and $4{ }^{\circ} \mathrm{C}$. Rubber particles (upper white rubbery layer), C-serum (middle aqueous layer) and 123 lutoids (bottom creamy layer) were identified andseparated for further purification as stated 124 below:

125

The rubber particles were first washed with ice cold buffer containing $20 \mathrm{mM}$ Tris-HCl, $300 \mathrm{mM}$ mannitol, $0.5 \mathrm{mM}$ DTT at $\mathrm{pH} 7.2$ in a ratio of $1: 10(\mathrm{w} / \mathrm{v})$. The suspension was stirred for $30 \mathrm{mins}$ and subsequently ultracentrifuged for 15 mins at $30,000 \mathrm{~g}$ and $4{ }^{\circ} \mathrm{C}$. The upper rubbery layer was collected. The C-serum was ultrtacentrifuged for 15 mins at 30,000 $\mathrm{g}$ and $4{ }^{\circ} \mathrm{C}$. The upper clear phase was collected. The lutoids were also added into ice cold buffer containing $20 \mathrm{mM}$ Tris$\mathrm{HCl}, 300 \mathrm{mM}$ mannitol, $0.5 \mathrm{mM}$ DTT at $\mathrm{pH} 7.2$ in a ratio of 1:10 (w/v). The suspension was stirred for 10 mins and subsequently ultracentrifuged for 15 mins at $30,000 \mathrm{~g}$ and $4{ }^{\circ} \mathrm{C}$. The bottom creamy layer was collected.

\subsubsection{Extraction of protein from different subcellular fractions}

These three different fractions (rubber particles, C-serum and lutoids) were respectively added in Borax/PVPP/Phenol (BPP) buffer containing $100 \mathrm{mM}$ EDTA, $100 \mathrm{mM}$ Tris (pH 8.0), $50 \mathrm{mM}$ Borax, $50 \mathrm{mM}$ Vitamin C, 1\% PVPP (w/v), 1\% Triton X-100 (v/v), 2\% $\beta$-mercaptoethanol (v/v) and $30 \%$ sucrose $(\mathrm{w} / \mathrm{v})$ in a ratio of 1:5 (w/v). The mixtures were vortexed for $30 \mathrm{mins}$.

For rubber particles, the mixture was sonicated for $5 \mathrm{~min}$ at $70 \mathrm{~W} / \mathrm{cm} 2$ in an ice bath and subsequently ultracentrifuged for 15 mins at 15,000 and $4{ }^{\circ} \mathrm{C}$. The clear phase was collected and two volumes of Tris-saturated phenol ( $\mathrm{pH} \mathrm{8.0)}$ were added. The mixture was then vortexed for 15 mins. For C-serum and lutoids, two volumes of Tris-saturated phenol ( $\mathrm{pH} \mathrm{8.0)}$ were added and vortexed for 15 mins.

All the mixtures were subsequently centrifuged for 15 mins at 15,000 and $4{ }^{\circ} \mathrm{C}$. The upper phase was collected and precipitated with 4 volumes of cold-acetone. The precipitated protein was washed with cold acetone and air-dried prior to fractionation. 


\subsection{Gelfree Protein fractionation}

Extracted protein samples from each subcellular fraction were then fractionated based on the molecular masses using GELFREE ${ }^{\mathrm{TM}} 8100$ fractionation system (Protein Discovery, U.S.A.). Mid-mass cartridge kit (fractionation of proteins with molecular masses between $3.5-150 \mathrm{kDa}$ ) was used in this experiment. Protein sample of $250 \mu \mathrm{g}$ (in solution) was mixed with acetate sample buffer $(30 \mu \mathrm{l})$ and DTT $(8 \mu \mathrm{l})$ to the final total volume of $150 \mu \mathrm{l}$ prior to fractionation. The fractionation conditions are as below:

\begin{tabular}{|l|l|l|l|l|l|l|l|l|l|l|l|l|l|}
\hline Voltage (V) & 50 & 50 & 50 & 50 & 50 & 100 & 100 & 100 & 100 & 100 & 100 & 100 & 100 \\
\hline $\begin{array}{l}\text { Fraction } \\
\text { interval (min) }\end{array}$ & 16 & 41.5 & 2 & 2 & 3 & 2 & 2 & 3 & 5 & 7 & 10 & 15 & 20 \\
\hline Fraction No. & - & 1 & 2 & 3 & 4 & 5 & 6 & 7 & 8 & 9 & 10 & 11 & 12 \\
\hline
\end{tabular}

Total of 12 fractions were collected and were stored at $-20{ }^{\circ} \mathrm{C}$ prior to further use.

\subsection{In-solution digestion}

All Gelfree fractions of protein were digested using trypsin separately according to the method of $\mathrm{Ru}$ et al. (2006). Samples were first undergone reduction and alkylation prior to digestion. Briefly, protein samples were solubilized in $500 \mu \mathrm{L}$ of denaturing buffer (6M guanidine$\mathrm{HCl} / 25 \mathrm{mM}$ ammonium bicarbonate, $\mathrm{pH} 8.5$ ). $250 \mu \mathrm{L}$ of $1 \mathrm{mg} / \mathrm{ml} \mathrm{DTT} / 25 \mathrm{mM}$ Ammonium bicarbonate was then added to the protein solution and incubated at $55^{\circ} \mathrm{C}$ for 30 minutes. Following, $500 \mu \mathrm{L}$ of $1 \mathrm{mg} / \mathrm{mL}$ iodoacetamide $/ 25 \mathrm{mM}$ ammonium bicarbonate was added, covered with aluminium foil and incubated at $55^{\circ} \mathrm{C}$ for 15 minutes.

The reduced and alkylated protein sample was then buffer exchanged with $25 \mathrm{mM}$ ammonium bicarbonate using spin-column with molecular cut-off of $3 \mathrm{kDa}$ for 3 times. $250 \mu \mathrm{L}$ of digestion buffer (25 $\mathrm{mM}$ ammonium bicarbonate) and trypsin (ratio 1:50) were then added to the sample and incubated at $37^{\circ} \mathrm{C}$ for $18 \mathrm{~h}$. The protein samples were then either stored at $-20^{\circ} \mathrm{C}$ or directly analyzed using mass spectrometry. 


\subsection{Mass spectrometry}

All LC MS and MS/MS analyses were carried out using Thermo LTQ/Orbitrap Velos (Thermo Scientific, San Jose, CA, USA) coupled with Easy-nLC II system (Thermo Scientific, San Jose, CA, USA). Chromatographic separation of tryptic-digested peptides was performed using EasyColumn C18-A2 $(100 \times 0.75$ mm i.d., $3 \mu \mathrm{m}$; Thermo Scientific, San Jose, CA, USA) coupled with pre-column (Easy-Column, $20 \times 0.1 \mathrm{~mm}$ i.d., $5 \mu \mathrm{m}$; Thermo Scientific, San Jose, CA, USA) at flow rate of $0.3 \mu \mathrm{l} / \mathrm{min}$ and injection volume of sample was $10 \mu \mathrm{l}$. Pre-column was equilibrated for $15 \mu \mathrm{l}$ at flow rate of $3 \mu \mathrm{l} / \mathrm{min}$ whereas analytical column was equilibrated for 4 $\mu 1$ at a flow rate of $0.3 \mu \mathrm{l} / \mathrm{min}$. Running buffers used were: (A) deionsed distilled water with $0.1 \%$ formic acid, and (B) acetonitrile with $0.1 \%$ formic acid. Gradient elution was performed from 5 to $100 \%$ buffer $B$ over 85 minutes and hold for another 15 minutes. The mass spectrometer was calibrated and mass calibration coefficients were determined using a mixture of caffeine, MRFA peptide and Ultramark 1600 for normal mass calibration and PPG 2700 with $7 \mathrm{mM}$ sodium acetate in $70 \%$ methanol for high mass calibration. Data acquisition was performed using Xcalibur ver. 2.1 (Thermo Scientific, San Jose, CA, USA) with mass tolerance threshold of $5 \mathrm{ppm}$. The eluant was electrosprayed into mass spectrometer at $2.3 \mathrm{kV}$ (source voltage) and capillary temperature of $200{ }^{\circ} \mathrm{C}$ was used.

Two MS/MS analysis methods were used for the peptide detection. The first method, dubbed as the proteomic approach, was able to analyze peptides in both high and low abundance while the second method, dubbed as the glycoproteomic approach, was able to analyze low abundant peptides and glycopeptides. For the proteomic approach, peptides were detected by full scan mass analysis from $\mathrm{m} / \mathrm{z}$ 300-2,000 at resolving power of 60,000 (at m/z 400, FWHM; 1-s acquisition) with data-dependent MS/MS analyses triggered by the 8 most abundant ions from the parent mass list of predicted peptides with rejection of singly or unassigned charge state. The MS/MS analysis was performed using the same resolving power $(60,000)$ and CID was conducted with isolation width of $2 \mathrm{Da}$, normalized collision energy of 35, activation $q$ of 0.25 , activation time of $50 \mathrm{~ms}$ and charge state of 2 . Whereas, HCD was conducted with isolation width of $2 \mathrm{Da}$, normalized collision energy of 35, activation time of $0.1 \mathrm{~ms}$ and FT first mass value $(\mathrm{m} / \mathrm{z})$ of 100 . ETD was conducted with isolation width of $2 \mathrm{Da}$, normalized energy of 35 , activation $\mathrm{q}$ of 0.25 , activation time of $100 \mathrm{~ms}$ and charge state of 3 and more. For the 
211 glycoproteomic approach, the mass spectrometric acquisition parameters were based on the work 212 of Julian Saba and colleagues (Saba et al., 2012). Briefly, the acquisition uses the 213 complementary fragmentations of ETD and HCD intelligently. ETD spectra are only acquired 214 when glycan oxonium ions from HCD fragmentation are detected. The oxonium ions are hexose, 215 hexosamine, hoxosamine fragments and hexose-hexosamine.

216

217

218

219

220

221

222

223

224

225

226

227

228

229

230

231

232

233

234

235

236

237

238

239

240

\subsection{Analysis of mass spectrometric data}

PEAKS were used to construct predicted peptide sequences using MS/MS data without the needs to refer to the known protein databases. PEAKS reads the RAW files generated by LC-MS/MS for all fractions of CID, HCD, and ETD of each C-serum, lutoids, and rubber particles and extracted the peptide information during Data Refinement. The charge options were set to 2-10 with filter quality of $>0.65$.

Automated peptide de novo sequencing was executed on each sample, combining all fractions in one de novo result. Parent mass error tolerance $0.1 \mathrm{Da}$ and fragment mass error tolerance $0.8 \mathrm{Da}$ with Trypsin digestion enzyme were inserted as the sequencing parameters. De novo sequencing uses all the extracted information from MS/MS data and predicts potential peptide sequences. The process produced a list of de novo peptide sequences identified from MS/MS spectra.

This was followed by a standard workflow of PEAKS databases identification (PEAKS DB + PEAKS PTM + SPIDER) against the rubber genome (RG) annotated databases (http://bioinfoccb.usm.my/cgi-bin/gb2/gbrowse/Rubber/), PlantGDB (http://www.plantgdb.org/) and SwissProt (http://www.uniprot.org/). The workflow started with PEAKS DB search, where the list of candidate peptides was aligned against protein of annotated databases. The parameter includes carbamidomethylation of cycteine and oxidation of methionine as variable modifications. The search continued with the second process in the workflow, PEAKS PTM, where post translation modifications were predicted and got included in the alignment. The parametes were set to all 670 types of modification as variable. Lastly, the SPIDER was used to find more mutations on the candidate peptides to identify more proteins. 
241 In all three workflow process, the peptide-spectrum matches (PSM) results were filtered using 242 high confidence peptide identification at 1\% FDR for databases with huge number of sequences 243 (>1000); AnnHBM, PlantGDB and SwissProt, while for the databases with small number of 244 sequences $(<1000)$; latex allergens, disease resistance, rubberwood formation, latex biosynthesis, 245 and photosynthesis, the filter $-10 \lg \mathrm{P}=20$ was used instead. The protein filter were set to $-10 \lg \mathrm{P}$ $246=0$ and 1 or more unique peptide hits. The FDR was calculated using a decoy database search.

The standard workflow results of CID, HCD, and ETD from each C-serum, lutoids, and rubber particles were compared using Venny (Oliveros, 2007) to develop Venn diagrams in order to determine the number of unique proteins found on each databases.

For the glycoproteomic method, the PEAKS PTM step was skipped; with selected glycosylation masses were included into the PEAKS DB step. The list of selected glycosylation and their masses is displayed in Table 1. All the result filter parameters from proteomic method were also use. The standard workflow results of glycoproteomic from $\mathrm{C}$-serum, lutoids, and rubber particles were compared using Venny before comparing both results of proteomic and 257 glycoproteomic.

\section{Results and Discussion}

Rubber latex is a very complex mixture of proteins as aforementioned. Therefore, fractionations according to the subcellular fraction and then based on molecular weight were performed prior to mass spectrometry analysis. This protocol would allow more low abundant proteins to be detected. The proteins found in this study were used to match to several established genome transcripted databases including latex allergens, disease resistance, photosynthesis, rubberwood

265 formation and latex biosynthesis databases.

Figure 1 displays the representative MS spectra from this experiment. Result showed that ions peaks with high resolution ranging from 24,000 to 63,000 were produced. The high resolution is essential for the identification and confirmation of the molecular formula of the peptide sequences and thus determines the mass accuracy of the molecular ions. Ion peaks with doubly

271 or higher charge were then selected to be fragmented. Figure 2 (Panels A-D) shows the 
272 representative MSMS fragments and the ion tables. These spectra have high signal-to-noise ratio 273 and show complete or near-complete backbone fragmentation. Low error $(<0.8 \mathrm{Da})$ was also 274 found in the data.

275 Figure 3 shows the coverage of $87 \%$ of a whole protein sequence as an example of high quality 276 protein de novo sequencing that has been acquired. The blue line underneath the protein 277 sequence indicates the identified peptide sequence which shows the high repeatability of the 278 peptide sequences in the analysis. The list of the supporting peptides is displayed in Table 2. It 279 could be observed that high accuracy (low in mass differences, ppm) were found in the data. 280 Note that identification of these proteins was not just high in percent coverage, also all these 281 MSMS spectra were collected at high resolution and mass accuracy. Therefore, the quality the 282 data collected was convincing.

Table 3 shows the summary of the total proteins found (proteomic method) in each subcellular 285 fraction according to different databases. C-serum, lutoids and rubber particles subcellular fractions contributed to high amount of protein in each database. C-serum contributed to the most amount of proteins identified in every genome transcripted database except for the latex biosynthesis database. For the 5 genome transcripted databases, it was shown that $97.3 \%$ (36 out of 37 proteins), 90.5\% (38 out of 42 proteins), 100\% (43 out of 43 proteins), $90.3 \%$ (290 out of 321 proteins), and $61 \%$ (372 out of 610 proteins) of the total non-redundant proteins were identified from the photosynthesis database, latex allergens database, rubberwood formation database, latex biosynthesis database, and disease resistance database, respectively. It could also be observed in Figure 4 that generally, C-serum, lutoids and rubber particle fractions shares the majority of common proteins. The number of proteins common to C-serum, lutoids and rubber particle for each of the genome translated database are 18, 28, 36, 115, and 103, respectively.

296 Table 4 shows the summary of the total proteins found (glycoproteomic method) in each 297 subcellular fraction according to different databases. This approach, unlike the conventional 298 glycomic methodology (Ismail et al., 2011), is not intended to rigorously characterize glycan 299 structures but more to selecting and sequencing glycoproteins in high throughput. This procedure 300 also does not require any offline sample enrichment steps thus can minimize sample losses. By 
301

302

303

304

305

306

307

308

309

310

311

312

313

314

315

316

317

318

319

320

321

322

323

324

325

326

327

328

329

using this glycoproteomic approach, although the number of proteins found is not as high as the proteomic approach but it has allowed the detection of low abundant glycoproteins that were not able to be detected via the proteomic approach. Results show clearly that the percentage of proteins identified has dropped significantly compared to proteomics method. For the 5 genome transcripted databases, it was shown that $64.9 \%$ (24 out of 37 proteins), $61.9 \%$ (26 out of 42 proteins), $69.8 \%$ (30 out of 43 proteins), 34.9\% (112 out of 321 proteins), and $20.7 \%$ (126 out of 610 proteins) of the total non-redundant proteins were identified from the photosynthesis database, latex allergens database, rubberwood formation database, latex biosynthesis database, and disease resistance database, respectively. All glycosylated peptides identified from the genome transcripted database through this approach were O-linked glycopeptides. Unfortunately, there were no glycosylated peptides identified in small rubber particle protein as declared by Wititsuwannakul (Wititsuwannakul et al., 2008). Also, Beta-1, 3-endoglucanase was identified but due to Ser-352 being replaced by Gly in cv. RRIM 600, Asn-350 was not glycosylated (Subroto et al., 2001). Generally, the majority of unique proteins identified by glycoproteomic method were found in C-serum, followed by lutoids and rubber particles (Figure 5).

Table 5 shows the summary of the total protein found in each method based on different database. By removing the protein redundancies found from both methods, more unique proteins were identified (Figure 6). Both photosynthesis and rubberwood formation database had all its protein identified. Both latex biosynthesis and disease resistance database got an increase percentage of protein identified, at $92.5 \%$ and $63.3 \%$, respectively, while latex allergen database stays at $90.5 \%$.

\subsection{Latex Biosynthesis}

The latex biosynthesis database is a collection of translated proteins involved in latex production in $H$. brasiliensis. The database consists of proteins from the entire metabolic pathway in which rubber biosynthesis took place starting from sucrose. Six major steps that can be further divided into 12 sub-metabolic pathways which involve proteins for sucrose import and degradation, glycolysis, acetyl-CoA biosynthesis, prenyl diphosphate synthesis via mevalonate pathway in cytosol, geranylgeranyl pyrophosphate synthesis in mitochondria and rubber polymerization on the rubber particle membrane were compiled. Rahman et al. had constructed the entire metabolic 
330

331

332

333

334

335

336

337

338

339

340

341

342

343

344

345

346

347

348

349

350

351

352

353

354

355

356

357

358

pathway of latex biosynthesis represented by 417 genes that encodes 321 proteins in the database and consists of 12 distinct sub-metabolic pathways (Rahman et al., 2013). We managed to identify a total of $297(92.5 \%)$ non-redundant proteins thru our analysis (Table 5). The major proteins that were identified includes beta- fructofuranosidase from both the sucrose import and the fructan synthesis pathway, the glycolysis related proteins; phosphopyruvate hydratase, phosphoglycerate mutase, phosphoglycerate kinase, fructose-bisphosphate aldolase, and glyceraldehyde-3-phosphate dehydrogenase. We also identified alpha-amylase, alpha glucosidase, and oligo-1, 6-glucosidase from the starch metabolism pathway, glucose-6phosphate 1-dehydrogenase from the pentose phosphate pathway, acetyl-CoA Cacetyltransferase from the acetyl-CoA biosynthesis pathway, carbonate dehydratase from the tricarboxylic acid (TCA) cycle pathway, hydroxymethylglutaryl-CoA synthase from the prenyl diphosphate synthesis via mevalonate (MVA) pathway, and also 4-hydroxy-3-methylbut-2-enyl diphosphate reductase from the 2-C-methyl-D-erythritol-4-phosphate (MEP) pathway. In addition, we also identified dimethylallyltranstransferase from the prenyl-PP biosynthesis pathway as well as rubber elongation factor and small rubber particle protein for the rubber polymerization pathway.

\subsection{Rubberwood}

The rubberwood database consists of proteins that involved in the formation of lignin in $H$. brasiliensis. As previously described by Rahman et al., 127 genes that encode 43 proteins in the database were identified for lignin formation in $H$. brasiliensis (Rahman et al., 2013). We managed to identify all $43(100 \%)$ non-redundant proteins thru our analysis (Table 5). Among the major proteins identified includes coniferin beta-glucosidase, cinnamyl-alcohol dehydrogenase, peroxidase, caffeic acid O-methyltransferase, and coniferyl-alcohol glucosyltransferase which are proteins involved in transport, storage, and mobilization of monolignols and its final polymerization into lignins.

\subsection{Disease Resistance}

The disease resistance database contains all proteins that involved in the defensive mechanism against diseases in $H$. brasiliensis that emphasized on a complete salicylic acid and jasmonic acid signaling pathway. It has been dedicated to develop a novel approach for controlling plant 
359 disease/pathogens. According to Rahman et al., the disease resistance genes includes 618 genes

360 from the nucleotide binding site - coding R gene family, 147 genes from the pathogenesis361 related proteins, and 96 genes combined from the hypersensitive response and systemic acquired 362 resistance (Rahman et al., 2013). All of these genes encode 610 proteins in the database. We 363 managed to identify a total of 388 (63.3\%) non-redundant proteins thru our analysis (Table 5). 364 Among the major proteins identified include disease resistance protein from the hypersensitive 365 response and systemic required resistance pathway, as well as putative disease resistance protein 366 and TMV resistance protein $\mathrm{N}$.

The latex allergens database contains proteins that are regarded as allergens, substances that cause allergic reaction. According to Rahman et al., allergens from H. brasiliensis includes both latex based allergens and non-latex allergens, which are made up of 100 and 16 genes respectively (Rahman et al., 2013). In combination, these genes encode for 42 proteins inside the

372 latex allergens database. We managed to identify a total of 38 (90.5\%) non-redundant proteins 373 thru our analysis (Table 5). Among the proteins identified are all 14 internationally recognized 374 natural rubber latex allergens, known as Hevb1 to Hevb14 (www.allergen.org). The proteins are 375 (in order from Hevb1 to Hevb14) rubber elongation factor, $\beta$-1,3-glucanase, small rubber 376 particle, lecithinase homolog, latex major allergen, havein, patatin-like, profilin, enolase, 377 superoxide dismutase, chitinase, lipid transfer precursor, esterase, and hevamine.

379 The photosynthesis database contains proteins that are involved in the photosynthesis 380 mechanism, particularly the Calvin cycle. There were 37 proteins in the database and we 381 managed to identify all $37(100 \%)$ non-redundant proteins thru our analysis (Table 5). Major 382 proteins identified include phosphoglycerate kinase, glyceraldehyde-3-phosphate dehydrogenase, 383 and fructose-biphosphate aldolase, which were enzymes involved in the Calvin cycle (Diwan, 384 2005). 
388

389

390

391

392

393

394

395

396

397

398

399

400

401

402

403

404

405

406

407

408

409

410

411

412

413

The AnnHBM, SwissProt, and PlantGDB database serves as a control to establish estimation as to how much identifiable proteins from the rubber latex could be obtained by using both the proteomic method and the glycoproteomic method. The AnnHBM database consists of 69103 proteins is the collection of all translated proteins from the $\mathrm{H}$. brasiliensis genome. The SwissProt and PlantGDB are both a collection of annotated proteins where SwissProt database is the collection of reviewed proteins from the UniProtKB while PlantGDB database is the collection of proteins derived from green plants. We managed to identify a total of 1839, 2324, and 4038 non-redundant proteins thru our analysis for AnnHBM, SwissProt, and PlantGDB database, respectively (Table 5). In both proteomic and glycoproteomic methods, more unique proteins were identified in each C-Serum, lutoids and rubber particle instead of common proteins (Figure 4 and Figure 5).

\section{Conclusion}

In general, we have successfully identified almost all rubber latex proteins in high percentage of coverage that were resulted by the high resolution and high mass accuracy mass spectrometric analysis. Therefore, the quality of the data collected was very convincing. The results shown here have successfully validated the genome databases generated in the previous study (Rahman et al., 2013).

\section{Acknowledgment}

We would like to thank the current and past members of the Centre for Chemical Biology (CCB) of University Sains Malaysia (USM) for providing the protein sequence database of genome translated H. brasiliensis and its subsequent biological pathways. This work was supported by grants from the APEX DE 2012 grant (1002/PDOPING/910335) and World First Discovery Innovation Fund (WFDI-1002/PDOPING/910203) from Universiti Sains Malaysia.

\section{Conflict of Interest}

The authors agree that there is no conflict of interest. 
414

415

416

417

418

419

420

421

422

423

424

425

426

427

428

429

430

431

432

433

434

435

436

437

438

439

440

441

442

443

444

445

446

447

448

449

450

451

452

453

454

455

456

457

458

\section{References}

1. Alenius, H., Palosuo, T., Kelly, Y., Kurup, V., Reunala, T., Makinen-Kiljunen, S., Turjanmaa, K., Fink, J., 1993. IgE reactivity to $14-\mathrm{kD}$ and $22-\mathrm{kD}$ natural rubber proteins in latex-allergic children with spina bifida and other congenital abnormalities. Int. Arch. Allergy Immunol. 102, 61-66.

2. Archer, B.L., Barnard, G., Cockbain, E.G.C., Dickenson, P.B., McMullen, A.I., 1963. Structure, composition and biochemistry of Hevea latex. In: Bateman (Ed.), Chemistry and Physics of rubber-like substances. McLaren and Sons, London, pp. 41-72.

3. Archer, B.L., Cockbain, E.G., 1955. The proteins of Hevea brasiliensis latex 2. Isolation of the a-globulin of fresh latex serum. Biochem. J. 61, 508-512.

4. Bokma E., Spiering M., Chow K.S., Mulder P.P.M.F.A., Subroto T., Beintema J.J., 2001. Determination of cDNA and genomic DNA sequences of hevamine, a chitinase from the rubber tree Hevea brasiliensis, Plant Physiol. Biochem. 39, 367-376.

5. Breton F., Coupé M., D’Auzac J., Sanier C., 1995. Demonstration of $\beta-1,3$-glucanase activities in lutoids of Hevea brasiliensis latex, J. Nat. Rubber Res. 10, 37-45.

6. Churngchow N., Suntaro A., Wititsuwannakul R., 1995. $\beta-1,3-$ Glucanase isozymes from the latex of Hevea brasiliensis, Phytochemistry 39, 505-509.

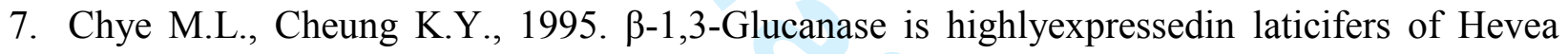
brasiliensis, Plant Mol. Biol. 29, 397-402.

8. Czuppon, A.B., Chen, Z., Rennert, S., Engelke, T., Meyer, H.E., Heber, M., Baur, X., 1993. The rubber elongation factor of rubber trees (Hevea brasiliensis) is the major allergen in latex. J. Allergy Clin. Immunol. 92, 690-697.

9. d'Auzac, J., Jacob, J.-L., 1969. Regulation of glycolysis in latex of Hevea brasiliensis. J. Rubb. Res. Inst. Malaya. 21, 417-444.

10. Dai L.J., Kang G.J, Li Y., Nie Z.Y., Duan C. F., Zheng R.Z., 2013. In-depth proteome analysis of the rubber particle of Hevea brasiliensis (para rubber tree). Plant Mol. Biol. 82, $155-168$.

11. Dickenson, P.B., 1969. Electron microscopical studies of the latex vessel system of Hevea brasiliensis. J. Rubb. Res. Inst. Malaya 21, 543-559.

12. Diwan, J.J., 2005. Photosynthetic Dark Reaction. Biochemistry and Biophysics, Rensselaer Polytechnic Institute.

13. Gomez, J.B., Hamzah, S., 1989. Particle size distribution in Hevea latex: some observations on the electron microscopic method. J. Nat. Rubb. Res. 4, 204-211. 
14. Hamzah, S.B., Gomez, J.B., 1982. Electron microscopy of ultracentrifuged fractions of Hevea latex. I. Top-fractions. J. Rubber Res. Inst. Malay. 30, 161-173.

15. Hasma, H., 1987. Proteolipids of natural rubber particles. J. Nat. Rubber Res. 2, 129-133.

16. Ismail, M.N., Stone, E., Panico, M., Lee S., Luu Y., Ramirez, K., Ho S., Fukuda, M., Marth J., Haslam S., Dell A. 2011. High sensitivity O-glycomic analysis of mice deficient in C2GnTs. Glycobiology. 21: 82-98.

17. Kongsawadworakul P., Viboonjun U., Romruensukharom P., Chantuma P., Ruderman S., Chrestin H., 2009. The leaf, inner bark and latex cyanide potential of Hevea brasiliensis: Evidence for involvement of cyanogenic glucosides in rubber yield. Phytochemistry, 70:730739.

18. Koyama, T., Wititsuwannakul, D., Asawatreratanakul, K., Wititsuwannakul, R., Ohya, N., Tanaka, Y., Ogura, K., 1996. Isopentenyl diphosphate isomerase in rubber latex. Phytochemistry 43, 769-772.

19. Moir, G.J., 1959. Ultrastructure and staining of Hevea latex. Nature, 184:1626-1628.

20. Oh, S.K., Kang, H., Shin, D.H., Yang, J., Chow, K.S., Yeang, H.Y., Wagner, B., Breiteneder, H., Han, K.H., 1999. Isolation, characterization, and functional analysis of a novel cDNA clone encoding a small rubber particle protein from Hevea brasiliensis. J. Biol. Chem. 274, $17132-17138$.

21. Oliveros, J.C. 2007. VENNY. An interactive tool for comparing lists with Venn Diagrams. http://bioinfogp.cnb.csic.es/tools/venny/index.html.

22. Rahman A.Y., Usharraj A.O., Misra B.B., Thottathil G.P., Jayasekaran K., Feng Y., Hou S., Ong S.Y., Ng F.L., Lee L.S., Tan H.S., Sakaff M.K., Teh B.S., Khoo B.F., Badai S.S., Aziz N.A., Yuryev A., Knudsen B., Dionne-Laporte A., Mchunu N.P., Yu Q., Langston B.J., Freitas T.A., Young A.G., Chen R., Wang L., Najimudin N., Saito J.A., Alam M., 2013. Draft genome sequence of the rubber tree Hevea brasiliensis. BMC Genomics, 14, 75.

23. Soedjanaatmadja U.M.S., Beintema J.J., Bruins A.P., Hofsteenge J., Jeronimus-Stratingh C.M., 1994. Demonstration by mass spectrometry that pseudo-hevein and hevein have ragged C-terminal sequences, Biochim. Biophys. Acta 1209, 144-148.

24. Southorn, W.A., 1969. Microscopy of Hevea latex. In: Proc Nat Rubb Res Conf 1996. Rubber Research Institute of Malaya, Kuala Lumper, pp. 766-776.

25. Southorn, W.A., Yip, E., 1968. Latex flow studies. III. Electrostatic considerations in the colloidal stability of fresh Hevea latex. J. Rubb. Res. Inst. Malaya. 20, 201-215.

26. Stintzi A., Fritig B., Geoffroy P., Heitz T., Kauffmann S., Legrand M., Prasad V., Wiedemann-Merdinoglu S., 1993. Plant 'pathogenesis-related' proteins and their role in defense against pathogens, Biochimie 75, 687-706. 
27. Subroto T., Beintema J.J., Schreuder H.A., Soedjanaatmadja U.M.S., Van Koningsveld G.A., 1996. Chitinase and $\beta$-1,3-glucanase in the lutoid-body fraction of Hevea latex, Phytochemistry 43, 29-37.

28. Sunderasan E., Cardosa M.J., Hamid S., Hamzah S., Yeang H.Y.,Ward M.A., 1995. Latex Bserum $\beta$-1,3-glucanase (Hev b II) and a component of the microhelix (Hev b IV) are major latex allergens, J. Nat. Rubber Res. 10, 82-99.

29. Suvachitanont, W., Wititsuwannakul, R., 1995. 3-Hydroxy-methyglutaryl-coenzyme A synthase in Hevea brasiliensis. Phytochemistry 40,757-761.

30. Tangpakdee, J., Tanaka, Y., Ogura, K., Koyama, T., Wititsuwannakul, R., Wititsuwannakul, D., 1997. Isopentenyl diphosphate isomerase and prenyl transferase activities in bottom fraction and C-serum from Hevea latex. Phytochemistry 45, 261-267.

31. Tata, S.J., Edwin, E.E., 1970. Hevea latex enzymes detected by zymogram technique after starch gel electrophoresis. J. Rubb. Res. Inst. Malaya 23, 1-12.

32. Wahler D., Colby T., Kowalski N.A., Harzen A., Wotzka S.Y., Hillebrand A., Fischer R., Helsper J., Schmidt J., Gronover C.S., Prufer D., 2012. Proteomic analysis of latex from the rubber-producing plant Taraxacum brevicorniculatum. Proteomics 12: 901-905.

33. Wei F., Xiao X.Z., Liu S.Z., 2008. A methodological research on extraction and twodimensional electrophoresis of lutoid proteins in rubber tree latex. Prog Mod Biomed, $8: 2258-2260$.

34. Wititsuwannakul, D., Rattanapittayaporn, A., Koyama, T., Wititsuwannakul, R., 2004. Involvement of Hevea latex organelle membrane proteins in rubber biosynthesis activity and regulatory function. Macromol. Biosci. 4, 314-323.

35. Wititsuwannakul, D., Wititsuwannakul, R., 2001. Biochemistry of Natural Rubber and Structure of Latex. In: Steinbuchel, A. (Ed.), Biopolymers, vol. 2. Wiley-VCH, Weiheim, Germany, pp. 151-202.

36. Wititsuwannakul, R., Wititsuwannakul, D., Dumkong, S., 1990. Hevea calmodulin: regulation of the activity of latex 3-hydroxy-3-methylglutarylcoenzyme A reductase. Phytochemistry 29, 1755-1758.

37. Wu K.X., Wang Z., Yao M.P., Chen X.T., Chen S.C., 2008. Comparative study of electrophoretic patterns of rubber particle proteins from different clones of Hevea brasiliensis. J Anhui Agri Sci, 36:15785-15787.

38. Yeang H.Y., Arif S.A.M., Yusof F., Sunderasan E., 2008. Allergenic proteins of natural rubber latex. Methods, 27:32-45. 
551 39. Yeang, H.Y., Cheong, K.F., Sunderasan, E., Hamzah, S., Chew, N.P., Hamid, S., Hamilton, R.G., Cardosa, M.J., 1996. The $14.6 \mathrm{kD}$ rubber elongation factor (Hev b 1) and $24 \mathrm{kD}$ (Hev b 3) rubber particle proteins are recognized by IgE from patients with spina bifida and latex allergy. J. Allergy Clin. Immunol. 98, 628-639.

40. Yeang, H.Y., Yip, E., Hamzah, S., 1995. Characterization of zone 1 and zone 2 rubber particles in Hevea brasiliensis latex. J. Nat. Rubber Res. 10, 108-123. 
559 Table 1: List of glycosylation

\begin{tabular}{|l|l|}
\hline Glycosylation & Mass \\
\hline Biantennary & 1622.58 \\
\hline Biantennary (-1 galactose) & 1460.53 \\
\hline Biantennary (-2 galactose) & 1298.48 \\
\hline Fucosylated biantennary (-1 galactose) & 1606.59 \\
\hline Fucosylated biantennary (-2 galactose) & 1444.53 \\
\hline Hex1HexNAc1 & 365.13 \\
\hline HexNAcylation (ST) & 203.08 \\
\hline N-linked glycan core & 1216.42 \\
\hline
\end{tabular}

560

561 
562 Table 2: Supporting peptide found in HBM_contig338536_s149176c3_gene1.protein.

\begin{tabular}{|c|c|c|c|c|c|}
\hline Peptide & $-10 \lg P$ & Mass & Start & End & PTM \\
\hline R.TPM(+15.99)GGFLGLLSTLPATKLGSIAIEAALKR.A & 70.66 & 2941.668 & 22 & 50 & Oxidation $(\mathrm{M})$ \\
\hline R.GIAAQDSGAFAWEIVPVEVSGGR.G & 67.45 & 2315.155 & 196 & 218 & \\
\hline K.ITGYADAAQAPELFTTAPALAIPK.A & 65.97 & 2429.284 & 287 & 310 & \\
\hline R.TPM(+15.99)GGFLGLLSTLPATK.L & 64.71 & 1718.928 & 22 & 38 & Oxidation $(\mathrm{M})$ \\
\hline R.REDQDNYAIHSFER.G & 63.41 & 1778.797 & 182 & 195 & \\
\hline R.TPMGGFLGLLSTLPATK.L & 62.02 & 1702.933 & 22 & 38 & \\
\hline R.ASVDPSLVQEVFFGNVLSANLGQAPAR.Q & 60.62 & 2785.44 & 51 & 77 & \\
\hline R.LGHDSVVDGM(+15.99)LK.D & 59.64 & 1285.634 & 144 & 155 & Oxidation (M) \\
\hline K.AVSNAGLDASQVDYYEINEAFAVVALANQK.L & 56.65 & 3169.557 & 311 & 340 & \\
\hline R.QAALGAGIPNSVVC(+57.02)TTVNK.V & 55.18 & 1898.988 & 78 & 96 & Carbamidomethylation \\
\hline R.EDQDNYAIHSFER.G & 54.03 & 1622.696 & 183 & 195 & \\
\hline R.TPM(+15.99)GGFLGLLSTLPATKLGSIAIEAALK.R & 53.65 & 2785.566 & 22 & 49 & Oxidation (M) \\
\hline A.PVAAAEIKPR.D & 51.68 & 1050.619 & 3 & 12 & \\
\hline T.GYADAAQAPELFTTAPALAIPK.A & 49.17 & 2215.152 & 289 & 310 & \\
\hline R.GKPSTSVDKDEGLGK.F & 49.16 & 1516.773 & 219 & 233 & \\
\hline M.APVAAAEIKPR.D & 49.16 & 1121.656 & 2 & 12 & \\
\hline R.GKPSTSVDKDEGLGKFDPVK.L & 48.7 & 2103.085 & 219 & 238 & \\
\hline $\begin{array}{l}\text { R.QAALGAGIPNSVVC }(+57.02) \text { TTVNKVC(+57.02)ASG } \\
\text { M(+15.99)K.A }\end{array}$ & 47.19 & 2648.308 & 78 & 103 & $\begin{array}{l}\text { Carbamidomethylation, } \\
\text { Oxidation (M) }\end{array}$ \\
\hline R.DVC(+57.02)IVGVAR.T & 44.97 & 987.5172 & 13 & 21 & Carbamidomethylation \\
\hline K.LGSIAIEAALKR.A & 42.96 & 1240.75 & 39 & 50 & \\
\hline $\begin{array}{l}\text { K.ATM(+15.99)LAAQSIQLGINDVVVAGGM(+15.99)ES } \\
\text { M(+15.99)SNAPK.Y }\end{array}$ & 42.67 & 3050.472 & 104 & 133 & Oxidation (M) \\
\hline $\begin{array}{l}\text { R.QAALGAGIPNSVVC }(+57.02) \text { TTVNKVC }(+57.02) \text { ASG } \\
\text { MK.A }\end{array}$ & 42.02 & 2632.314 & 78 & 103 & Carbamidomethylation \\
\hline K.LGSIAIEAALK.R & 36.86 & 1084.649 & 39 & 49 & \\
\hline K.LGLQVIAK.I & 34.85 & 840.5433 & 279 & 286 & \\
\hline P.VAAAEIKPR.D & 32.96 & 953.5658 & 4 & 12 & \\
\hline F.TTAPALAIPK.A & 31.98 & 981.5858 & 301 & 310 & \\
\hline R.KLRPSFK.E & 31.21 & 874.5388 & 241 & 247 & \\
\hline K.FDPVKLR.K & 29.19 & 873.5072 & 234 & 240 & \\
\hline L.SANLGQAPAR.Q & 26.01 & 983.5148 & 68 & 77 & \\
\hline K.YLAEAR.K & 24.6 & 721.3759 & 134 & 139 & \\
\hline R.LGHDSVVDGMLK.D & 24.5 & 1269.639 & 144 & 155 & \\
\hline L.VLVSGETALK.L & 24.46 & 1015.591 & 269 & 278 & \\
\hline $\begin{array}{l}\text { K.ATMLAAQSIQLGINDVVVAGGM(+15.99)ESMSNAP } \\
\text { K.Y }\end{array}$ & 19.61 & 3018.482 & 104 & 133 & Oxidation (M) \\
\hline A.AAEIKPR.D & 17.03 & 783.4603 & 6 & 12 & \\
\hline $\begin{array}{l}\text { A.GNAS(+365.13)S(+365.13)ISDGAAALVLVSGETALK } \\
\text { LGLQVIAK.I }\end{array}$ & 16.57 & 3682.914 & 256 & 286 & Hex1HexNAc1 \\
\hline
\end{tabular}


567 Table 3: Summary of the total protein found in each subcellular fraction of latex (with at least 1 568 unique peptide) (proteomics method)

\begin{tabular}{|c|c|c|c|c|c|}
\hline & C-Serum & Lutoids & RParticle & $\begin{array}{c}\text { Non- } \\
\text { redundant } \\
\text { Total }\end{array}$ & $\begin{array}{c}\text { Percentage } \\
(\%)\end{array}$ \\
\hline Photosynthesis & 31 & 28 & 27 & 36 & 97.3 \\
\hline Latex allergens & 34 & 34 & 34 & 38 & 90.5 \\
\hline $\begin{array}{l}\text { Rubberwood } \\
\text { formation }\end{array}$ & 42 & 40 & 39 & 43 & 100 \\
\hline $\begin{array}{c}\text { Latex } \\
\text { biosynthesis }\end{array}$ & 201 & 220 & 212 & 290 & 90.3 \\
\hline $\begin{array}{c}\text { Disease } \\
\text { resistance }\end{array}$ & 260 & 210 & 227 & 372 & 61 \\
\hline AnnHBM & 845 & 671 & 649 & 1745 & \\
\hline SwissProt & 1120 & 594 & 754 & 2095 & \\
\hline PlantGDB & 1849 & 1201 & 1236 & 3642 & \\
\hline
\end{tabular}


571 Table 4: Summary of the total protein found in each subcellular fraction of latex (with at least 1

572 unique peptide) (glycoproteomics method)

\begin{tabular}{|c|c|c|c|c|c|}
\hline & C-Serum & Lutoids & RParticle & $\begin{array}{c}\text { Non- } \\
\text { redundant } \\
\text { Total } \\
\end{array}$ & $\begin{array}{c}\text { Percentage } \\
(\%)\end{array}$ \\
\hline Photosynthesis & 15 & 6 & 9 & 24 & 64.9 \\
\hline Latex allergens & 18 & 12 & 16 & 26 & 61.9 \\
\hline $\begin{array}{l}\text { Rubberwood } \\
\text { formation }\end{array}$ & 20 & 13 & 13 & 30 & 69.8 \\
\hline $\begin{array}{c}\text { Latex } \\
\text { biosynthesis }\end{array}$ & 59 & 34 & 50 & 112 & 34.9 \\
\hline $\begin{array}{c}\text { Disease } \\
\text { resistance }\end{array}$ & 43 & 50 & 49 & 126 & 20.7 \\
\hline AnnHBM & 264 & 146 & 66 & 404 & \\
\hline SwissProt & 400 & 117 & 74 & 557 & \\
\hline PlantGDB & 748 & 230 & 125 & 1025 & \\
\hline
\end{tabular}

573

574 
575 Table 5: Summary of the total protein found (with at least 1 unique peptide)

576 (proteomics+glycoproteomics)

\begin{tabular}{|c|c|c|c|c|}
\hline & Proteomics & Glycoproteomics & $\begin{array}{c}\text { Non- } \\
\text { redundant } \\
\text { Total } \\
\end{array}$ & $\begin{array}{c}\text { Percentage } \\
(\%)\end{array}$ \\
\hline Photosynthesis & 36 & 24 & 37 & 100 \\
\hline Latex allergens & 38 & 26 & 38 & 90.5 \\
\hline $\begin{array}{l}\text { Rubberwood } \\
\text { formation }\end{array}$ & 43 & 30 & 43 & 100 \\
\hline $\begin{array}{c}\text { Latex } \\
\text { biosynthesis }\end{array}$ & 290 & 112 & 297 & 92.5 \\
\hline $\begin{array}{c}\text { Disease } \\
\text { resistance }\end{array}$ & 372 & 126 & 388 & 63.3 \\
\hline AnnHBM & 1745 & 404 & 1839 & \\
\hline SwissProt & 2095 & 557 & 2324 & \\
\hline PlantGDB & 3642 & 1025 & 4038 & \\
\hline
\end{tabular}


579

580

581

582

583

584

585

586

587

588

589

590

591

592

593

594

595

596

597

598

599

600

601

602

603

604

605

606

607

608

609

Figure 1 Representative MS spectra of HBM_contig260697_s115748c12_gene1.protein

Figure 2 (Panel A) Representative MSMS spectra of peptide sequence of AAVPSESTGLYEALELR in HBM_contig260697_s115748c12_gene1.protein

Figure 2 (Panel B) Representative MSMS spectra of peptide sequence of KLVLPVPAFNVINGGSHAGNK in HBM_contig260697_s115748c12_gene1.protein

Figure 2 (Panel C) Representative MSMS spectra of peptide sequence of ACNALLLKVNQIGSVTESTEAVK in HBM_contig260697_s115748c12_gene1.protein

Figure 2 (D) Representative MSMS spectra of peptide sequence of SGETDTFIADLSVGLATGQIK in HBM_contig260697_s115748c12_gene1.protein

Figure 3 The whole protein sequence of HBM_contig338536_s149176c3_gene1.protein with the identified peptide sequences (blue line below the protein sequence)

Figure 4 Venn diagrams of the numbers of protein found in each subcellular fractions based on database: (a) photosynthesis, (b) latex allergens, (c) rubberwood formation, (d) latex biosynthesis, (e) disease resistance, (f) annHBM, (g) SwissProt, and (h) PlantGDB. (See Supplementary Tables 1a-1h for the full list of proteins identified from each database).

Figure 5 Venn diagrams of the numbers of protein and glycoprotein found in each subcellular fractions based on database: (a) photosynthesis, (b) latex allergens, (c) rubberwood formation, (d) latex biosynthesis, (e) disease resistance, (f) annHBM, (g) SwissProt, and (h) PlantGDB. (See Supplementary Tables $2 \mathrm{a}-2 \mathrm{~h}$ for the full list of proteins identified from each database).

Figure 6 Venn diagrams of the numbers of protein and glycoproteins found in each extraction method based on database: (a) photosynthesis, (b) latex allergens, (c) rubberwood formation, (d) latex biosynthesis, (e) disease resistance, (f) annHBM, (g) SwissProt, and (h) PlantGDB. (See Supplementary Tables $3 \mathrm{a}-3 \mathrm{~h}$ for the full list of proteins identified from each database). 


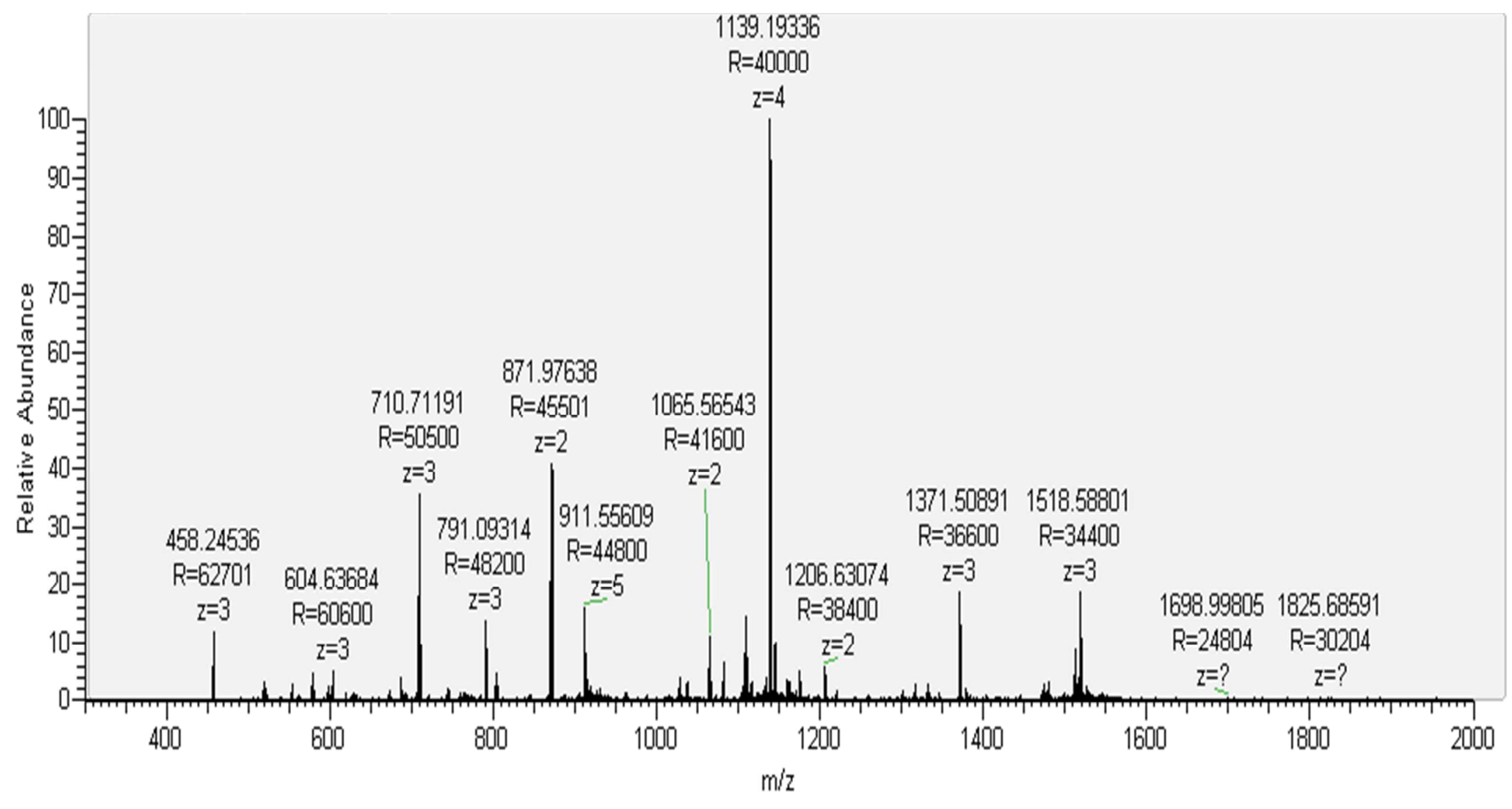

$\mathrm{R}:$ Resolution

Z : charge state

Figure 1 Representative MS spectra of HBM_contig260697_s115748c12_gene1.protein 


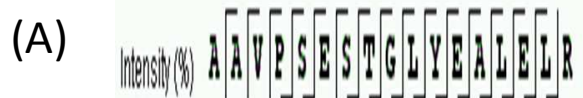

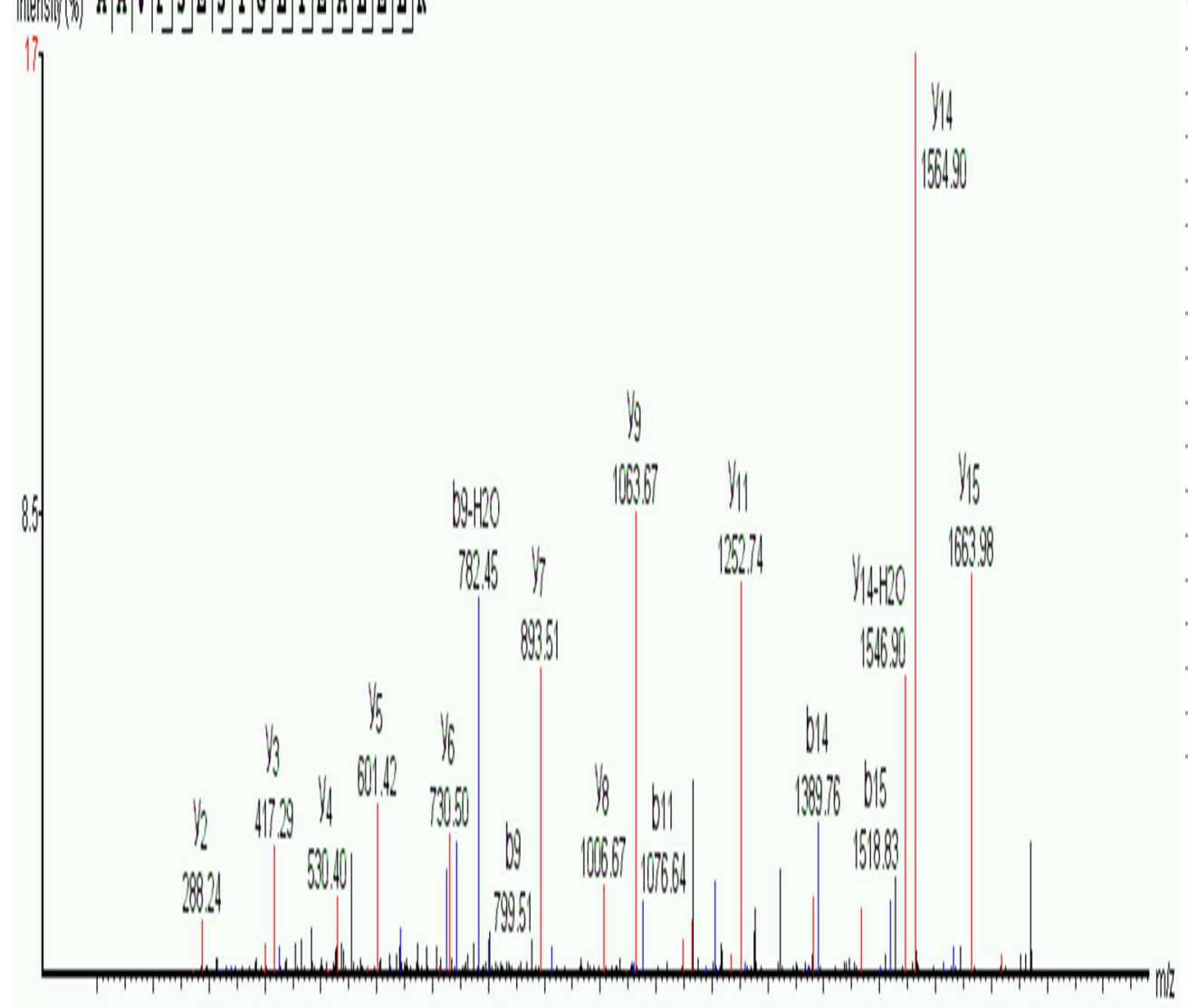

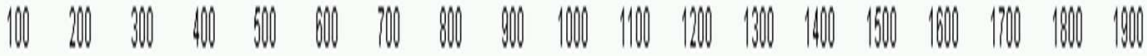

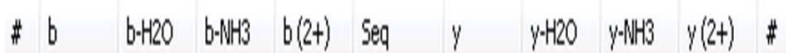

\begin{tabular}{l|c|c|c|c|c|c|c|c|c|c}
1 & 72.04 & 54.03 & 55.02 & 36.52 & A & & & & & 17 \\
\hline 2 & 143,08 & 125.07 & 126.06 & 72.04 & A & 1734.89 & 1716.88 & 1718.23 & 867,05 & 16
\end{tabular}

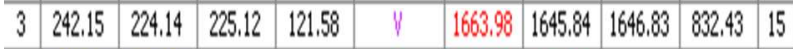

\begin{tabular}{l|l|l|l|l|l|l|l|l|l|l|}
\hline 4 & 339,24 & 321.29 & 322.18 & 170.10 & $P$ & 1564,90 & 1546,90 & 1547,76 & 782,89 & 14 \\
\hline
\end{tabular}

\begin{tabular}{l|l|l|l|l|l|l|l|l|l|l|}
\hline 5 & 426.36 & 400.22 & 409.21 & 213.62 & 5 & 1467.86 & 1449.72 & 1450.71 & 734.37 & 13 \\
\hline
\end{tabular}

\begin{tabular}{l|l|l|l|l|l|l|l|l|l|l|}
\hline 6 & 555.28 & 537,27 & 538,25 & 278.14 & $E$ & 1380,77 & 1362,69 & 1363.59 & 690,85 & 12 \\
\hline
\end{tabular}

\begin{tabular}{l|l|l|l|l|l|l|l|l|l|l|}
\hline 7 & 642.38 & 624.34 & 625.23 & 321.65 & 5 & 1251.72 & 1233.65 & 1234.73 & 626.33 & 11 \\
\hline 8
\end{tabular}

\begin{tabular}{|l|l|l|l|l|c|l|l|l|l|l|l|}
\hline 8 & 743.87 & 725.01 & 726.33 & 372.18 & $\uparrow$ & 1164.73 & 1146.62 & 1147,69 & 582.81 & 10
\end{tabular}

\begin{tabular}{l|l|l|l|l|l|l|l|l|l|l|}
\hline$g$ & 800,79 & 782.45 & 783.35 & 400,69 & $G$ & 1063.67 & 1045.57 & 1046.83 & 532.29 & 9 \\
\hline
\end{tabular}

\begin{tabular}{|l|l|l|l|l|l|l|l|l|l|l|}
\hline 10 & 913.52 & 895.45 & 896.44 & 457.23 & 1 & 1006.67 & 980.55 & 999.53 & 503.78 & 8 \\
\hline
\end{tabular}

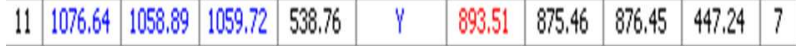

\begin{tabular}{|l|l|l|l|l|l|l|l|l|l|l|l|l}
12 & 1205.66 & 1187.56 & 1188.55 & 603.28 & $E$ & 730.50 & 712,57 & 713,38 & 365.70 & 6 \\
\hline
\end{tabular}

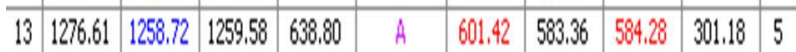

\begin{tabular}{|l|l|l|l|l|l|l|l|l|l|l|}
\hline 14 & 1389,76 & 1371.83 & 1372.75 & 695.35 & $L$ & 530,40 & 512.40 & 513.41 & 265.66 & 4 \\
\hline
\end{tabular}

\begin{tabular}{|l|l|l|l|l|l|l|l|l|l|l|l}
\hline 15 & 1518.83 & 1500.77 & 1501.71 & 759.87 & E & 417.29 & 399.19 & 400.26 & 209.12 & 3 \\
\hline
\end{tabular}

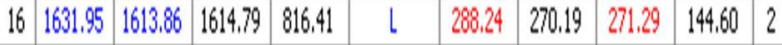

\begin{tabular}{|l|l|l|l|l|l|l|l|l|l|l|}
\hline 17 & & & & & $R$ & 175.12 & 157.11 & 158,09 & 88,06 & 1 \\
\hline
\end{tabular}

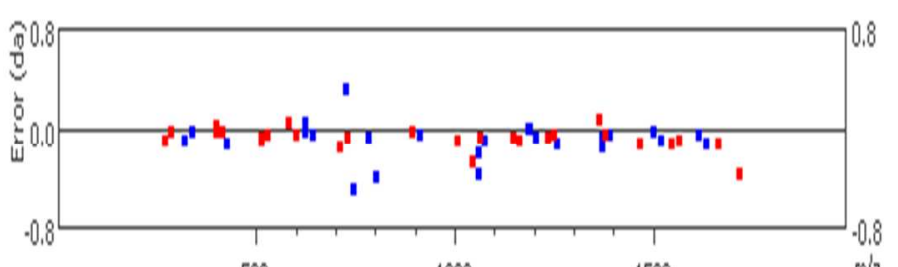

500

1500

mis

Figure 2 (Panel A) Representative MSMS spectra of peptide sequence of AAVPSESTGLYEALELR in HBM_contig260697_s115748c12_gene1.protein 
(B)

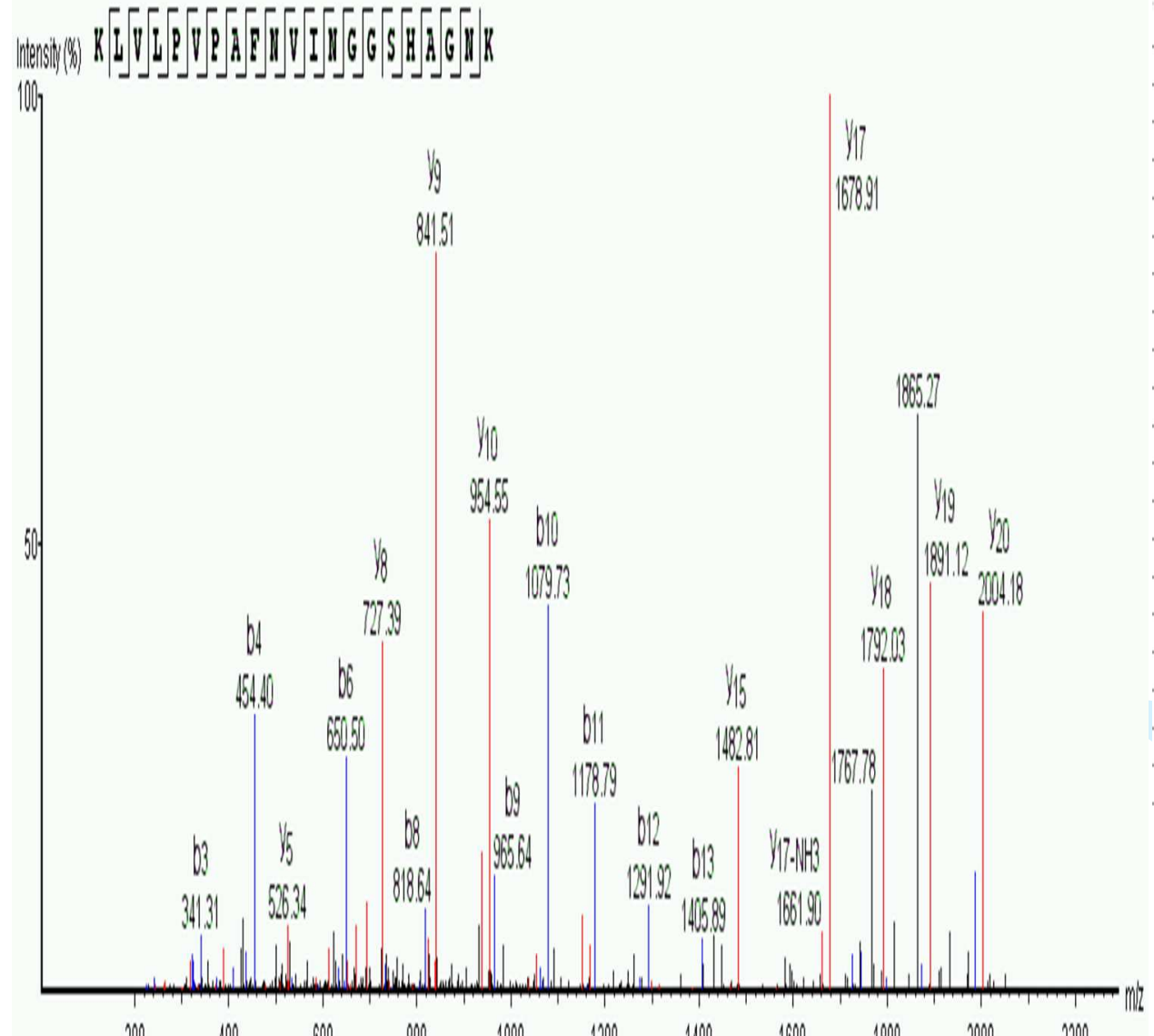

\begin{tabular}{|c|c|c|c|c|c|c|c|c|c|c|}
\hline & b & $\mathrm{b}-\mathrm{H} 2 \mathrm{O}$ & $\mathrm{b}-\mathrm{NH} 3$ & $b(2 t)$ & Seq & $y$ & $y-H 2 O$ & $y=N+3$ & $y(2+)$ & \# \\
\hline 1 & 129.10 & 111.09 & 112,08 & 65.05 & K & & & & & 21 \\
\hline 2 & 242.20 & 224.18 & 225.19 & 121.59 & $L$ & 4.18 & 1986.20 & 1987,08 & 1002.55 & 20 \\
\hline 3 & 341.31 & 323.35 & 324.28 & 171.13 & V & 1891.12 & 1873.01 & 1873.99 & 946.01 & 19 \\
\hline 4 & 454.40 & 436.38 & 437,34 & 227,09 & L & 1792,03 & 1773.94 & 1774.92 & 896.47 & 18 \\
\hline 5 & 551.39 & 533.83 & 533.83 & 276.20 & $p$ & 1678.91 & 1660.86 & 1661.90 & 839.49 & 17 \\
\hline 6 & 650.50 & 632.45 & 633.53 & 326.27 & $x^{2}$ & 1581.81 & 1563.80 & 1564.79 & 790.61 & 16 \\
\hline 7 & 747.52 & 729.50 & 730,49 & 374,30 & P & 1482.81 & 1464.73 & 1465.91 & 741.46 & 15 \\
\hline 8 & 818.64 & 800.54 & 801.52 & 410,32 & A & 1385.90 & 1367,68 & 1368.67 & 693.40 & 14 \\
\hline 9 & 965.64 & 947.61 & 948.59 & 483.31 & $F$ & 1314.79 & 1296.64 & 1297,69 & 657.24 & 13 \\
\hline 10 & 1079.73 & 1061.65 & 1062.83 & 540.33 & $\mathrm{~N}$ & 1167.59 & 1149,58 & 1150.68 & 585.02 & 12 \\
\hline 11 & 1178.79 & 1160.72 & 1161.82 & 589.34 & 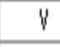 & 1053.69 & 1035.53 & 1036.65 & 527.78 & 11 \\
\hline 12 & 1291.92 & 1273.85 & 1274.79 & 645.91 & I & 954.55 & 936.46 & 937.52 & 477.24 & 10 \\
\hline 13 & 1405.89 & 1387,85 & 1388.83 & 703.43 & 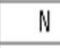 & 841.51 & 823.40 & 824.36 & 421.20 & 9 \\
\hline 14 & 1462,88 & 1444.87 & 1445.85 & 731.97 & 3 & 727.39 & 709.34 & 710.32 & 364.17 & 8 \\
\hline 15 & 1519,90 & 1501.89 & 1502,87 & 760.45 & G & 670.38 & 652.34 & 652.93 & 335.73 & 7 \\
\hline 16 & 1606.93 & 1588.92 & 1589.91 & 804.53 & 5 & 613.38 & 595.29 & 596.28 & 307.15 & 6 \\
\hline 17 & 1744.11 & 1726.18 & 1726.18 & 872.50 & $H$ & 526.34 & 508.26 & 509.35 & 263.68 & 5 \\
\hline 18 & 1815.03 & 1797,02 & 1798.27 & 908.01 & A & 389.23 & 371.23 & 372.19 & 195.11 & 4 \\
\hline 19 & 1871.95 & 1854.04 & 1855.02 & 936.52 & G & 318.21 & 300.27 & 301.08 & 159.59 & 3 \\
\hline 20 & 1986.20 & 1968.08 & 1969.07 & 993.55 & $\mathrm{~N}$ & 261.24 & 243.15 & 244.18 & 131.08 & 2 \\
\hline 21 & & & & & $K$ & 147,11 & 129.10 & 130,09 & 74.06 & 1 \\
\hline
\end{tabular}

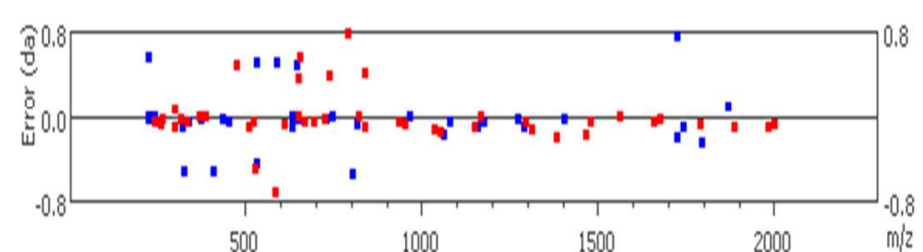

500 \begin{tabular}{l|l|l|l|l|l|l|l|l|l|l|}
1 & 129.10 & 111.09 & 112.08 & 65.05 & $K$ & & & & & 21 \\
\hline 2 & 242.20 & 224.18 & 225.19 & 121.59 & $L$ & 2004.18 & 1986.20 & 1987.08 & 1002.55 & 20 \\
\hline
\end{tabular} \begin{tabular}{|l|l|l|l|l|l|l|l|l|l|l|}
\hline 3 & 341.31 & 323.35 & 324.28 & 171.13 & $V$ & 1891.12 & 1873.01 & 1873.99 & 946.01 & 19 \\
\hline
\end{tabular} \begin{tabular}{|l|l|l|l|l|l|l|l|l|l|l|}
\hline 5 & 551.39 & 533.83 & 533.83 & 276.20 & $P$ & 1678.91 & 1660.86 & 1661.90 & 839.49 & 17 \\
\hline 6 & 650.5 & 632.45 & 633.53 & 36.27 & $V$ & 159.81 & 153.80 & 1564.79 & 7906 & 16
\end{tabular} \begin{tabular}{|l|l|l|l|l|l|l|l|l|l|l|}
\hline 7 & 747.52 & 729.50 & 730.49 & 374.30 & $\rho$ & 1482.81 & 1464.73 & 1465.91 & 741.46 & 15 \\
\hline
\end{tabular} \begin{tabular}{|l|l|l|l|l|l|l|l|l|l|}
\hline 1462.88 & 1444.87 & 1445.85 & 731.97 & $G$ & 727.39 & 709.34 & 710.32 & 364.17 & 8 \\
\hline
\end{tabular} \begin{tabular}{|l|l|l|l|l|l|l|l|l|l|l|l|}
1519,90 & 1501.89 & 1502.87 & 760.45 & $G$ & 670,38 & 652.34 & 652.93 & 335.73 & 7 \\
\hline
\end{tabular} \begin{tabular}{|l|l|l|l|l|l|l|l|l|l|l|}
\hline 17 & 1744.11 & 1726.18 & 1726.18 & 872.50 & $H$ & 526.34 & 508.26 & 509.35 & 263.68 & 5 \\
\hline
\end{tabular} $\begin{array}{lllllll}K & 147.11 & 129.10 & 130.09 & 74.06 & 1\end{array}$

Figure 2 (Panel B) Representative MSMS spectra of peptide sequence 
(C)

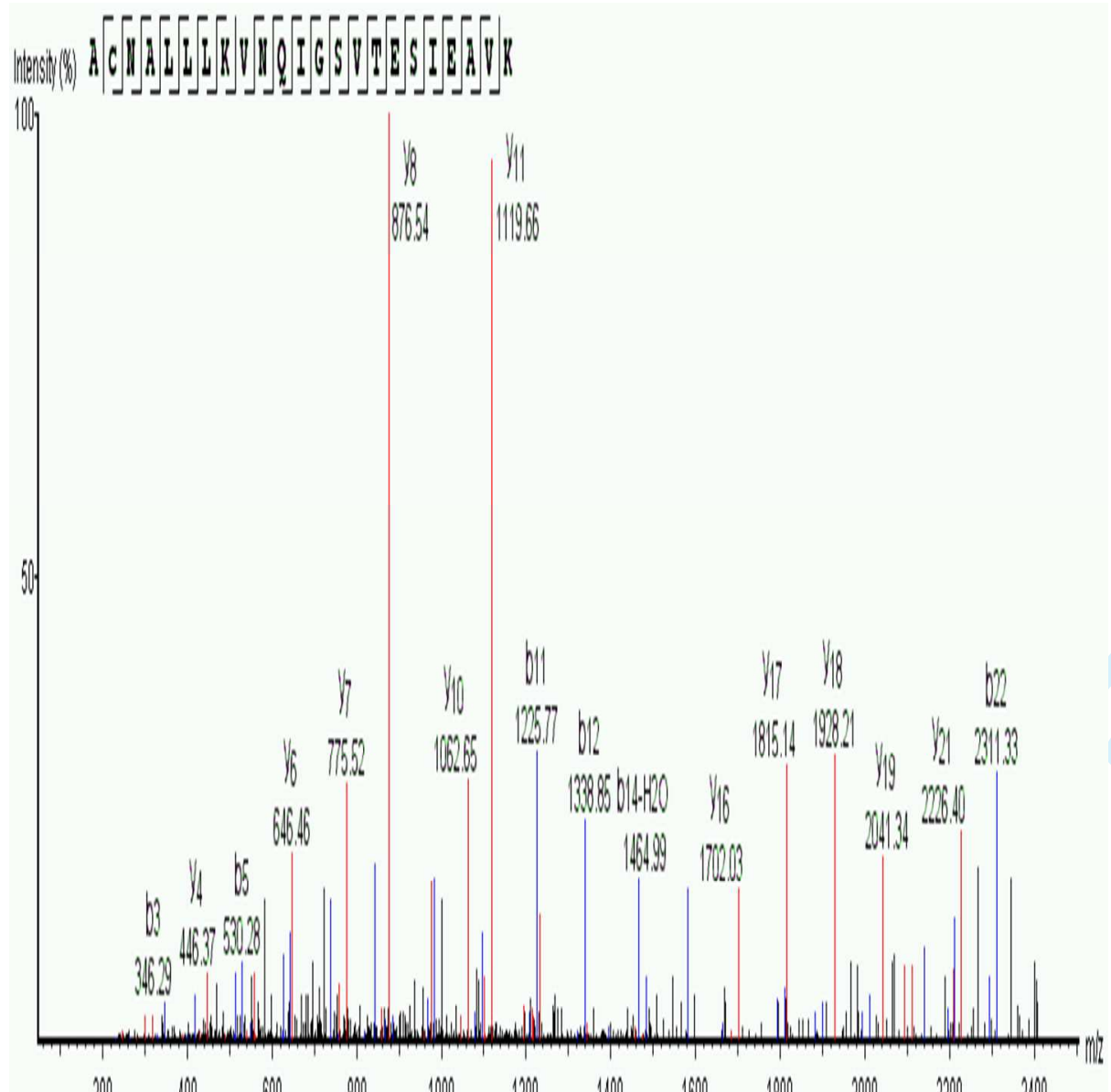

$\begin{array}{lllllllllll}\text { \# b } & b-H 2 O & b-N H 3 & b(2+) & \text { Seq } & y & y-H 2 O & y-N H 3 & y(2+) & \#\end{array}$

\begin{tabular}{c|c|c|c|c|c|c|c|c|c|c|}
1 & 72.04 & 54.03 & 55.02 & 36.52 & A & & & & & 23 \\
\hline
\end{tabular}

\begin{tabular}{|l|l|l|l|l|l|l|l|l|l|l|}
2 & 232.08 & 214.07 & 215.05 & 116.54 & $C(+57.02)$ & 2386.30 & 2368.29 & 2369.27 & 119.77 & 22 \\
\hline 3 & 346.29 & 328.25 & 329.26 & 173.56 & $\mathrm{~N}$ & 2226.40 & 2208.38 & 2209.24 & 1113.64 & 21 \\
\hline
\end{tabular}

\begin{tabular}{|l|l|l|l|l|l|l|l|l|l|l|}
\hline 4 & 417.30 & 399,38 & 400.21 & 209.08 & A & 2112.29 & 2094.37 & 2095.20 & 1056.61 & 20 \\
\hline
\end{tabular}

\begin{tabular}{|l|l|l|l|l|l|l|l|l|l|l|}
\hline 5 & 530.28 & 512.36 & 513.25 & 265.23 & $\mathrm{~L}$ & 2041.34 & 2023.18 & 2024.16 & 1021.10 & 19 \\
\hline 6 & 643.40 & 625.55 & 626.39 & 322.16 & $\mathrm{~L}$ & 1928.21 & 1900.10 & 191.08 & 964.55 & 18 \\
\hline
\end{tabular}

\begin{tabular}{l|l|l|l|l|l|l|l|l|l|l|}
\hline 6 & 643.40 & 625.55 & 626.39 & 322.16 & $\mathrm{~L}$ & 1928.21 & 1910.10 & 1911.08 & 964.55 & 18 \\
\hline 7 & 756.81 & 738.40 & 739.45 & 378.70 & $\mathrm{~L}$ & 185.14 & 1797.01 & 1798.00 & 908.01 & 17
\end{tabular}

\begin{tabular}{|l|l|l|l|l|l|l|l|l|l|l|}
\hline 7 & 756.81 & 738.40 & 739.45 & 378.70 & $\mathrm{~L}$ & 1815.14 & 1797.01 & 1798.00 & 908.01 & 17 \\
\hline 8 & 884.53 & 866.55 & 867.48 & 442.75 & $K$ & 1702.03 & 1684.23 & 1684.91 & 851.47 & 16 \\
\hline
\end{tabular}

\begin{tabular}{l|l|l|l|l|l|l|l|l|l|l|}
\hline 8 & 884.53 & 866.55 & 867.48 & 442.75 & $K$ & 1702.03 & 1684.23 & 1684.91 & 851.47 & 16 \\
\hline 9 & 983.69 & 965.56 & 966.89 & 492.29 & & 1573.84 & 1555.83 & 1556.82 & 787.42 & 15 \\
\hline
\end{tabular}

\begin{tabular}{|l|l|l|l|l|l|l|l|l|l|l|}
\hline 9 & 983.69 & 965.56 & 966.89 & 492.29 & $V$ & 1573.84 & 1555.83 & 1556.82 & 787.42 & 15 \\
\hline
\end{tabular}

\begin{tabular}{l|l|l|l|l|l|l|l|l|l|l|}
\hline 10 & 1097.65 & 1079.57 & 1080.59 & 549.67 & $\mathrm{~N}$ & 1475.02 & 1456.86 & 1457.75 & 737.89 & 14 \\
\hline
\end{tabular}

\begin{tabular}{|l|l|l|l|l|l|l|l|l|l|l|}
\hline 11 & 1225.77 & 1207.79 & 1208.65 & 613.34 & $Q$ & 1360.73 & 1342.84 & 1343.70 & 680.87 & 13 \\
\hline
\end{tabular}

\begin{tabular}{|l|l|l|l|l|l|l|l|l|l|l|}
\hline 12 & 1338.85 & 1320.75 & 1321.85 & 669.88 & I & 1232.79 & 1214.74 & 1215.80 & 616.84 & 12 \\
\hline
\end{tabular}

\begin{tabular}{|l|l|l|l|l|l|l|l|l|l|l|}
\hline 13 & 1395.78 & 1377.77 & 1378.75 & 698.39 & $G$ & 1119,66 & 1101.62 & 1103.05 & 560.18 & 11 \\
\hline
\end{tabular}

\begin{tabular}{|l|l|l|l|l|c|c|c|c|c|c|}
\hline 14 & 1483.02 & 1464.99 & 1465.78 & 741.91 & 5 & 1062.65 & 1044.81 & 1045.54 & 531.78 & 10 \\
\hline
\end{tabular}

\begin{tabular}{|l|l|l|l|l|l|l|l|l|l|l|}
\hline 15 & 1581.98 & 1563.87 & 1564.85 & 791.44 & $\gamma$ & 975.61 & 957.53 & 958.11 & 488.35 & $g$ \\
\hline
\end{tabular}

\begin{tabular}{|l|l|l|l|l|c|c|c|c|c|c|}
\hline 16 & 1682.93 & 1664.48 & 1665.90 & 842.39 & $T$ & 876.54 & 858.50 & 859.44 & 438.73 & 8 \\
\hline
\end{tabular}

\begin{tabular}{|l|l|l|l|l|l|l|l|l|l|l|}
\hline 17 & 1811.50 & 1793.92 & 1794.94 & 906.48 & E & 775.52 & 757.49 & 758.39 & 388.30 & 7 \\
\hline
\end{tabular}

\begin{tabular}{|l|l|l|l|l|l|l|l|l|l|l|}
\hline 18 & 1898.95 & 1881.22 & 1881.97 & 950.00 & 5 & 646.46 & 628.37 & 629.35 & 323.69 & 6 \\
\hline
\end{tabular}

\begin{tabular}{|l|l|l|l|l|l|l|l|l|l|l|}
19 & 2012.19 & 1994.46 & 1995.06 & 1006.54 & I & 559.37 & 541.33 & 542.32 & 280.15 & 5 \\
\hline
\end{tabular}

\begin{tabular}{l|l|l|l|l|l|l|l|l|l|l|}
\hline 20 & 2141.16 & 2123.12 & 2124.10 & 1071.06 & E & 446.37 & 428.25 & 429.30 & 223.63 & 4 \\
\hline
\end{tabular}

\begin{tabular}{l|l|l|l|l|l|l|l|l|l|l|}
21 & 2212.18 & 2194.15 & 2195.29 & 1106.58 & A & 317.26 & 299.22 & 300.19 & 159.11 & 3 \\
\hline
\end{tabular}

\begin{tabular}{|l|l|l|l|l|l|l|l|l|l|l|}
\hline 22 & 2311.33 & 2293.20 & 2294.21 & 1156.12 & $V$ & 246.16 & 228.17 & 229.15 & 123.59 & 2 \\
\hline
\end{tabular}

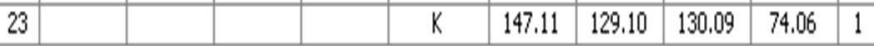

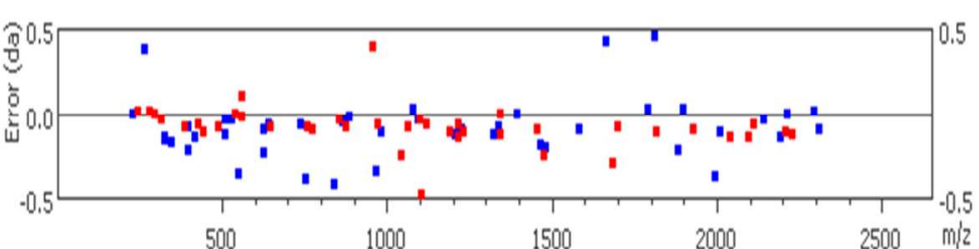

500

1000

1500

2000

Figure 2 (Panel $\quad$ C) Representative MSMS spectra of peptide sequence of ACNALLLKVNQIGSVTESTEAVK in 


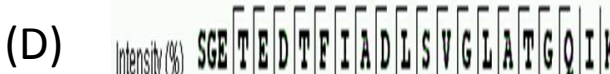

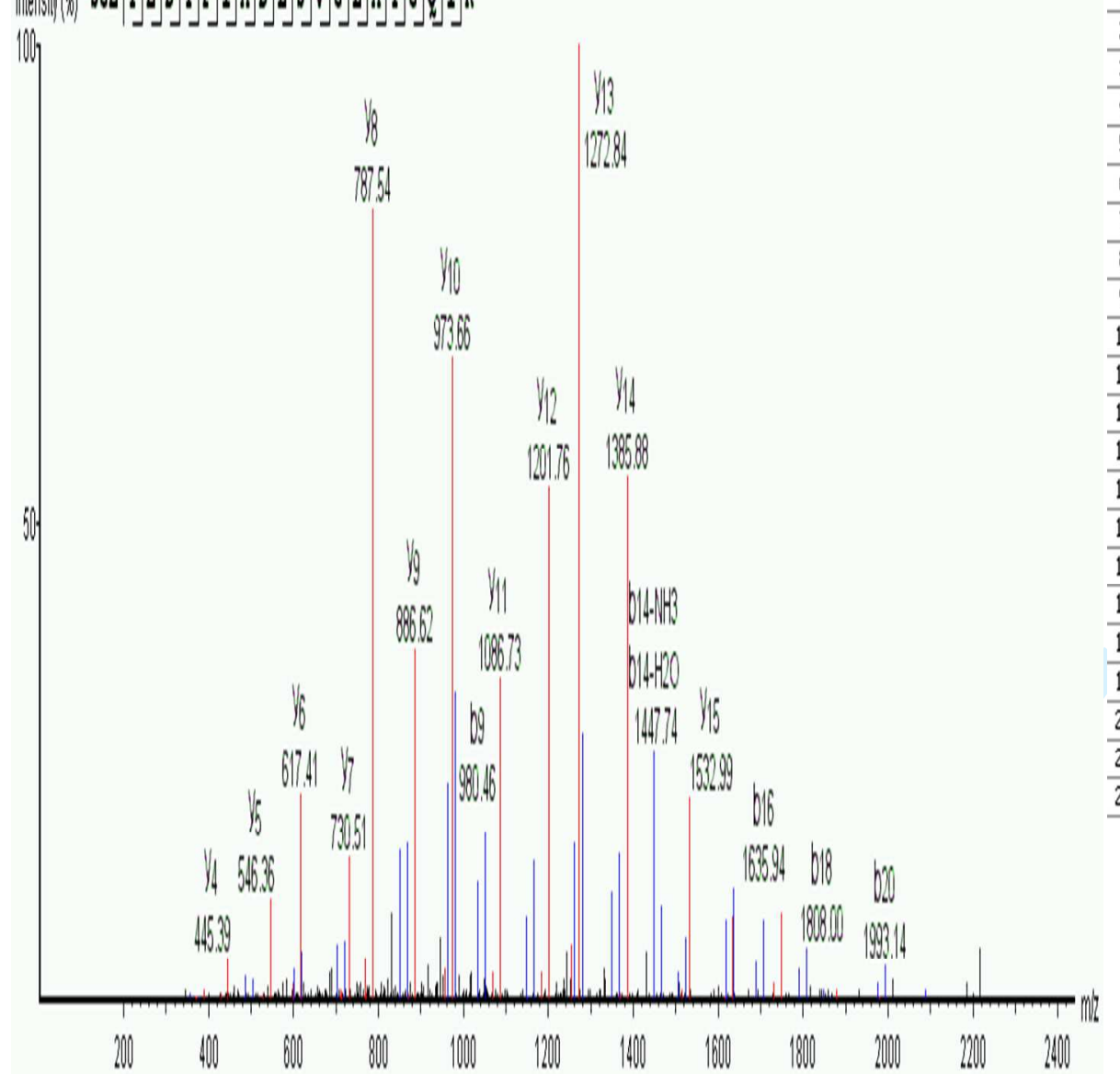

$\begin{array}{llllllllll}* & b & b-H 2 O & b-N H 3 & b(2+) & 5 e q & y & y-H 2 O & y-N H 3 & y(2+)\end{array}$

\begin{tabular}{c|c|c|c|c|c|c|c|c|c|c|}
1 & 88.04 & 70.03 & 71.01 & 44.52 & 5 & & & & & 22 \\
\hline 2 & 145.06 & 127.05 & 128.03 & 73.03 & 6 & 2165.10 & 2147.09 & 2148.07 & 1083.05 & 21
\end{tabular}

\begin{tabular}{|l|l|l|l|l|l|l|l|l|l|l|l|}
\hline 2 & 145.06 & 127.05 & 128,03 & 73.03 & $G$ & 2165.10 & 2147,09 & 2148.07 & 1083.05 & 21. \\
\hline & 274.10 & 256.09 & 257,08 & 137.55 & E & 2108,08 & 2090,07 & 2091.05 & 1054.54 & 20 \\
\hline
\end{tabular}

\begin{tabular}{c|c|c|c|c|c|c|c|c|c|c|}
\hline 3 & 274.10 & 256.09 & 257.08 & 137.55 & E & 2108.08 & 2090.07 & 2091.05 & 1054.54 & 20 \\
\hline 4 & 375.32 & 357.15 & 358.12 & 188.08 & T & 1979.17 & 1961.02 & 1962.01 & 990.02 & 19 \\
\hline
\end{tabular}

\begin{tabular}{|l|l|l|l|l|l|l|l|l|l|l|l|}
\hline 5 & 504.20 & 486.26 & 487.17 & 252.60 & E & 1878.16 & 1859.97 & 1860.96 & 939.49 & 18 \\
\hline 6 & 619.28 & 60.22 & 692.19 & 310.11 & $D$ & 174.10 & 1731.09 & 1731.79 & 874.97 & 17 \\
\hline
\end{tabular}

\begin{tabular}{|l|l|l|l|l|l|l|l|l|l|l|}
\hline 6 & 619.28 & 601.22 & 602.19 & 310.11 & $D$ & 1749.10 & 1731.09 & 1731.79 & 874.97 & 17 \\
\hline 7 & 720.34 & 72.33 & 703.24 & 360.63 & 1 & 1634.06 & 165.91 & 1617.05 & 817.46 & 16 \\
\hline
\end{tabular}

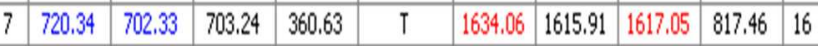

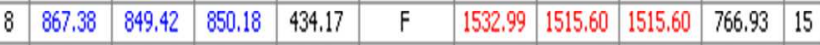

\begin{tabular}{l|l|l|l|l|l|l|l|l|l|l|l|}
\hline g & 980.46 & 962.49 & 963.39 & 490.71 & I & 1385.88 & 1368.45 & 1368.45 & 693.40 & 14 \\
\hline
\end{tabular}

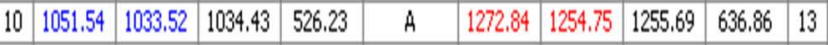

\begin{tabular}{l|l|l|l|l|l|l|l|l|l|l|}
\hline 11 & 1166.57 & 1148.59 & 1149.96 & 583.74 & $D$ & 1201.76 & 1183.75 & 1184.65 & 601.34 & 12 \\
\hline 12 & 129.64 & 121.62 & 1262.54 & 640.28 & & 1086.73 & 1088.8 & 1069.62 & 543.83 & 11 \\
\hline
\end{tabular}

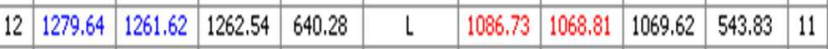

\begin{tabular}{|l|l|l|l|l|l|l|l|l|l|l|}
\hline 13 & 1366.66 & 1348.70 & 1349.57 & 683.80 & 5 & 973.66 & 955.64 & 956.54 & 487.28 & 10 \\
\hline
\end{tabular}

\begin{tabular}{|l|l|l|l|l|l|l|l|l|l|l|}
\hline 14 & 1465.73 & 1447.74 & 1448.27 & 733.33 & $V$ & 886.62 & 867.92 & 869.66 & 443.77 & 9 \\
\hline
\end{tabular}

\begin{tabular}{|l|l|l|l|l|l|l|l|l|l|l|l|}
\hline 15 & 1522.79 & 1504.71 & 1505.23 & 761.85 & $G$ & 787.54 & 769.59 & 770.17 & 394.23 & 8 \\
\hline
\end{tabular}

\begin{tabular}{|l|l|l|l|l|l|l|l|l|l|l|}
\hline 16 & 1635.94 & 1617.87 & 1619.35 & 818.39 & $\mathrm{~L}$ & 730.51 & 712.52 & 713.35 & 365.72 & 7 \\
\hline
\end{tabular}

\begin{tabular}{|l|l|l|l|l|l|l|l|l|l|l|}
\hline 17 & 1706.96 & 1688.93 & 1689.79 & 853.91 & A & 617.41 & 599.44 & 600.48 & 309.18 & 6 \\
\hline
\end{tabular}

\begin{tabular}{|l|l|l|l|l|l|l|l|l|l|l|}
\hline 18 & 1808.00 & 1789.94 & 1790.83 & 904.43 & $T$ & 546.36 & 528.31 & 529.34 & 273.66 & 5 \\
\hline
\end{tabular}

\begin{tabular}{|l|l|l|l|l|l|l|l|l|l|l|}
\hline 19 & 1865.05 & 1847.01 & 1848.04 & 932.94 & 6 & 445.39 & 427.27 & 428.57 & 223.14 & 4 \\
\hline
\end{tabular}

\begin{tabular}{|l|l|l|l|l|l|l|l|l|l|l|}
\hline 20 & 1993.14 & 1975.10 & 1975.91 & 996.97 & $Q$ & 388.36 & 370.27 & 371.35 & 194.63 & 3 \\
\hline
\end{tabular}

\begin{tabular}{|l|l|l|l|l|l|l|l|l|l|l|}
\hline 21 & 2106.02 & 2088.30 & 2088.30 & 1053.51 & $\mathrm{I}$ & 260.20 & 242.19 & 243.17 & 130.60 & 2 \\
\hline 22 & & & & & $\mathrm{~K}$ & 147.11 & 129.10 & 130.09 & 74.06 & 1 \\
\hline
\end{tabular}

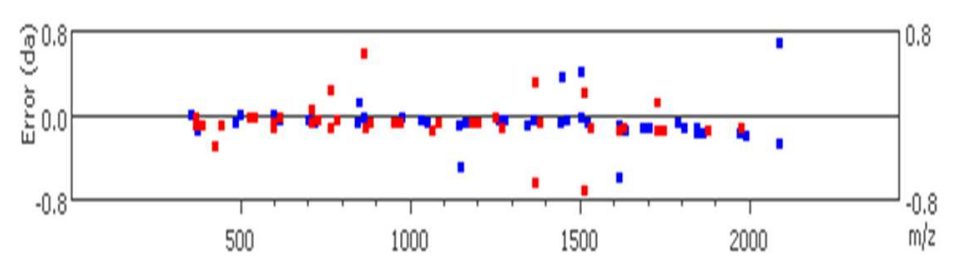

Figure 2 (D) Representative MSMS spectra of peptide sequence of SGETDTFIADLSVGLATGQIK in HBM_contig260697_s115748c12_gene1.protein 


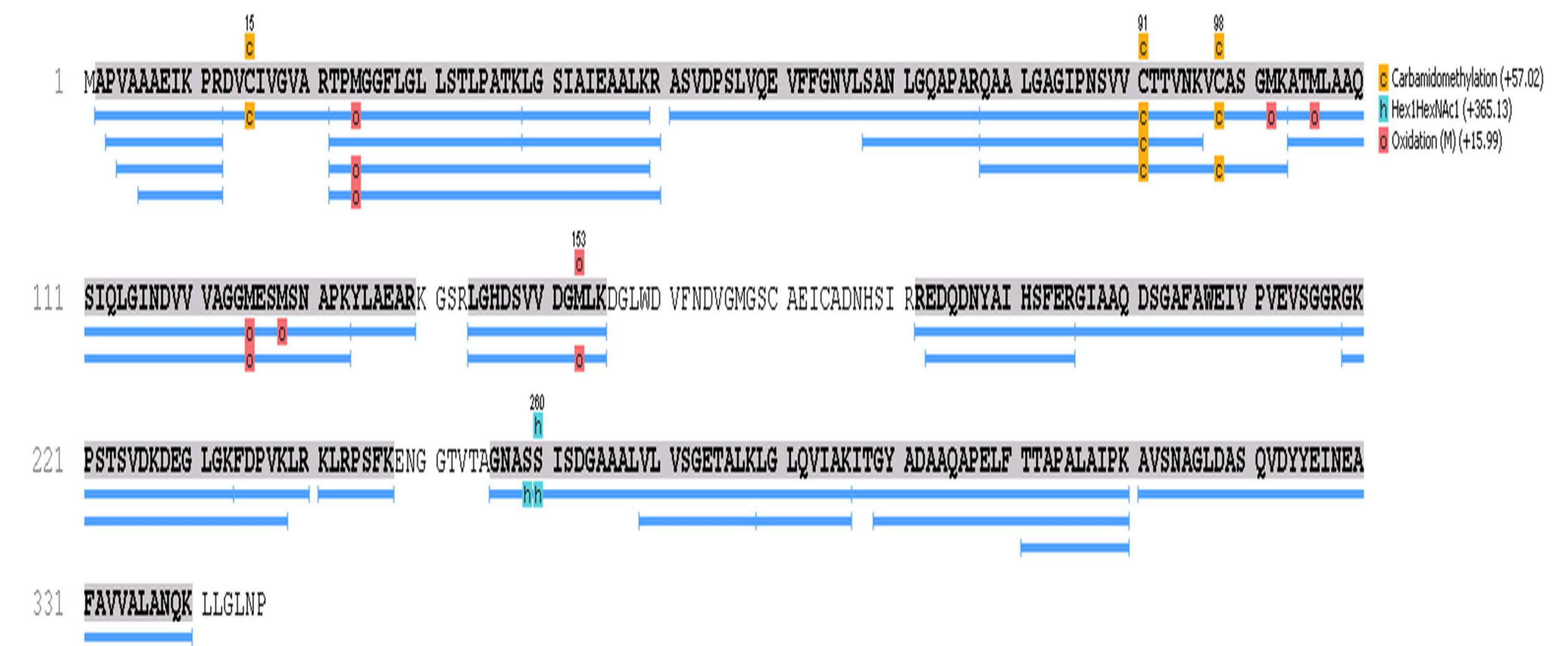

Figure 3 The whole protein sequence of HBM_contig338536_s149176c3_gene1.protein with the identified peptide sequences (blue line below the protein sequence) 
(a)

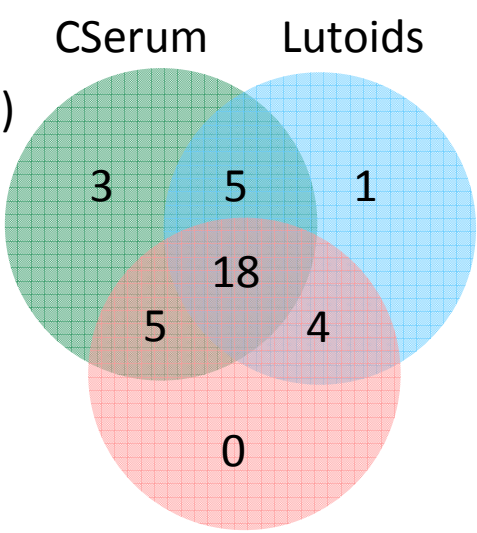

RParticle

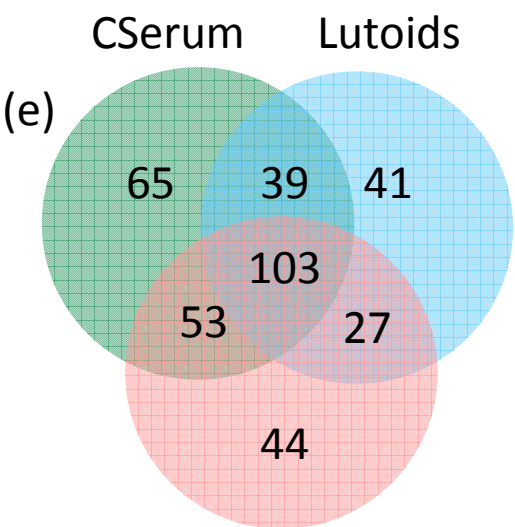

RParticle

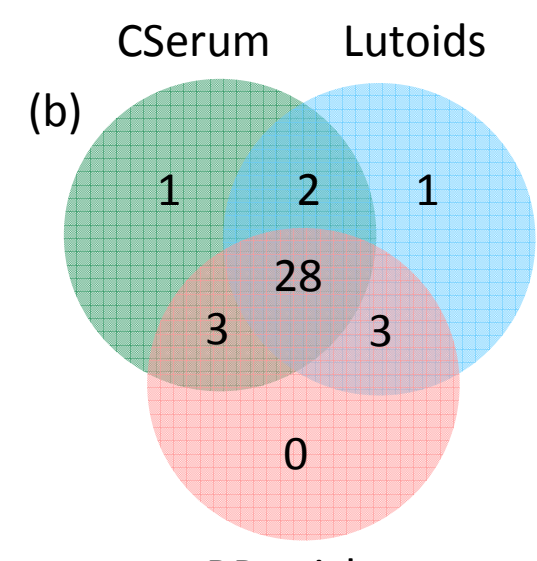

RParticle

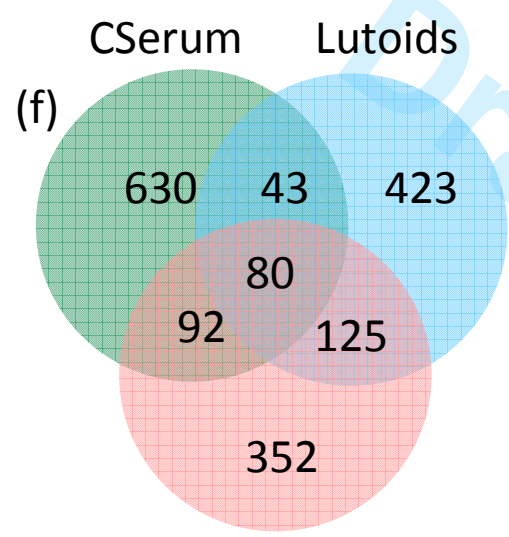

RParticle

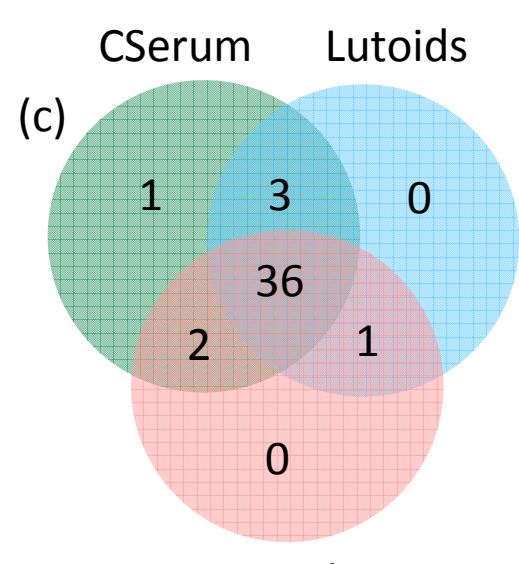

RParticle

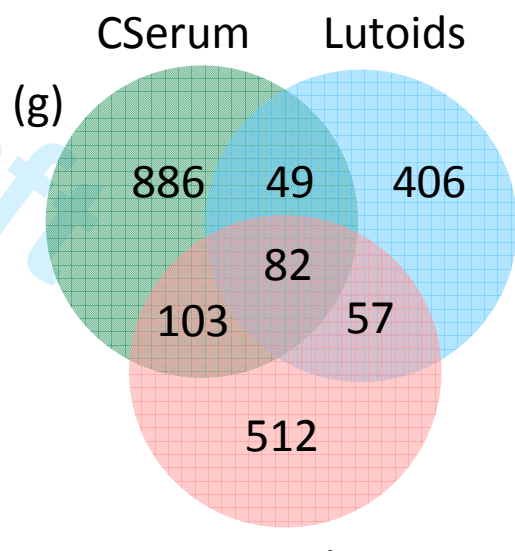

RParticle
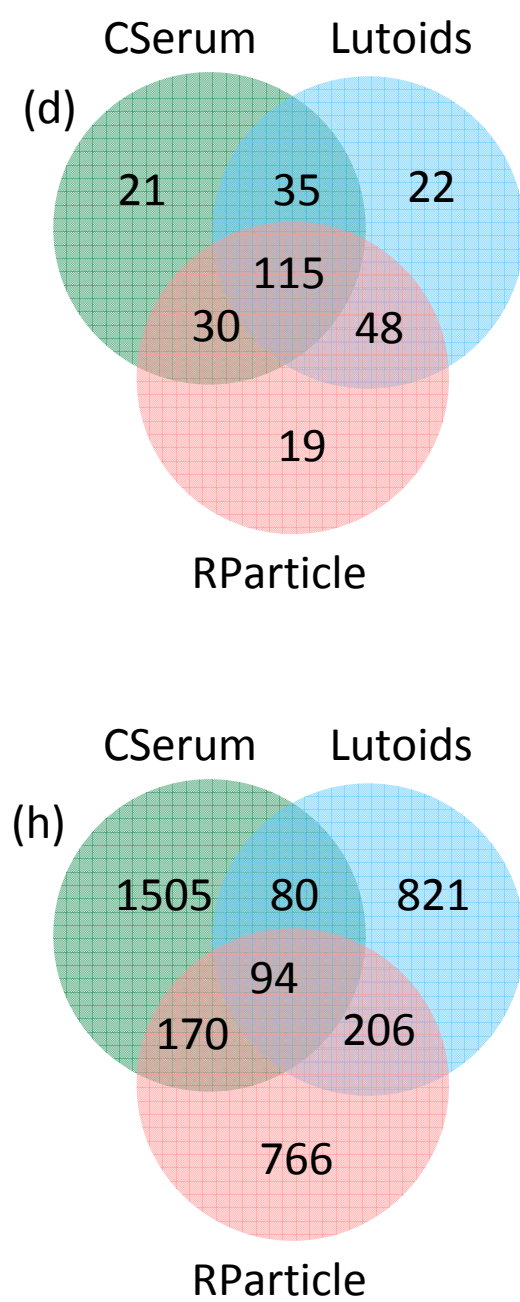

Figure 4 Venn diagrams of the numbers of protein found in each subcellular fractions based on database: (a) photosynthesis, (b) latex allergens, (c) rubberwood formation, (d) latex biosynthesis, (e) disease resistance, (f) annHBM, (g) SwissProt, and (h) PlantGDB. (See Supplementary Tables $1 \mathrm{a}-1 \mathrm{~h}$ for the full list of proteins identified from each database). 
(a)

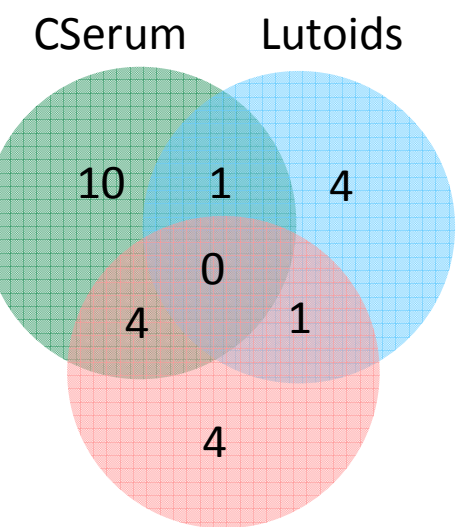

RParticle

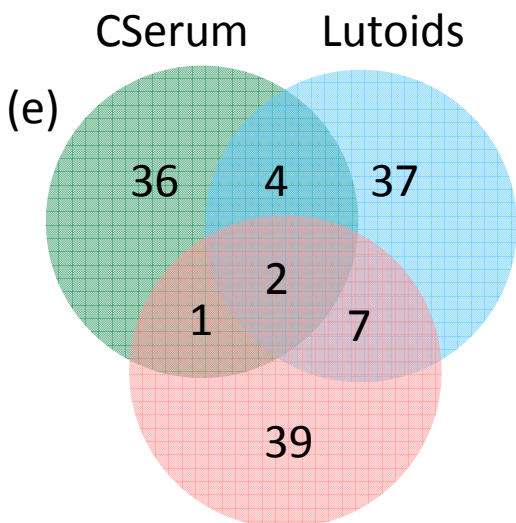

RParticle

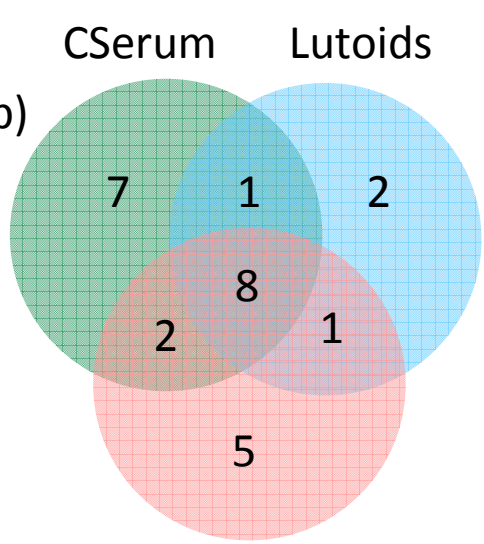

RParticle

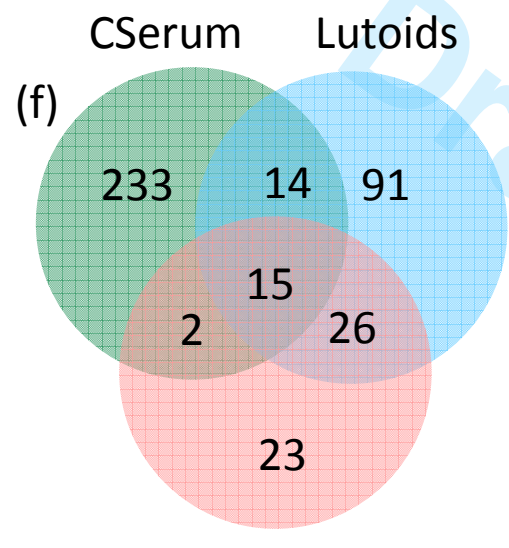

RParticle

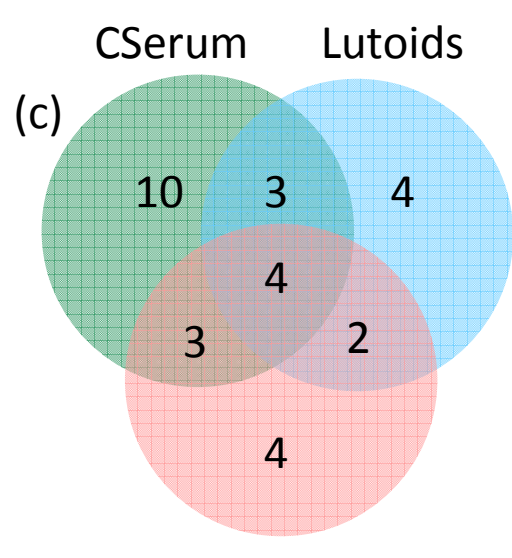

RParticle

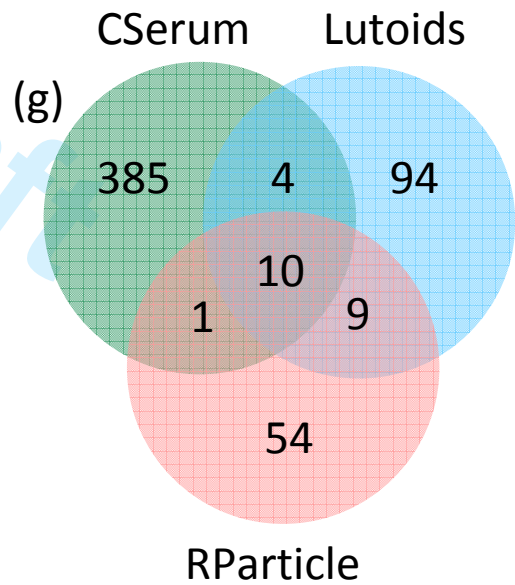

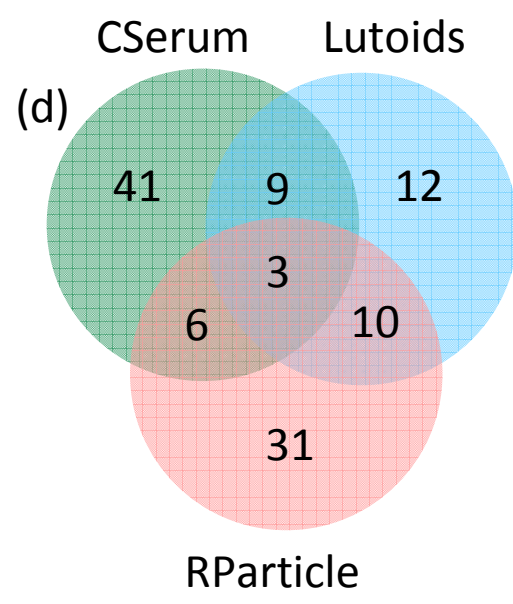

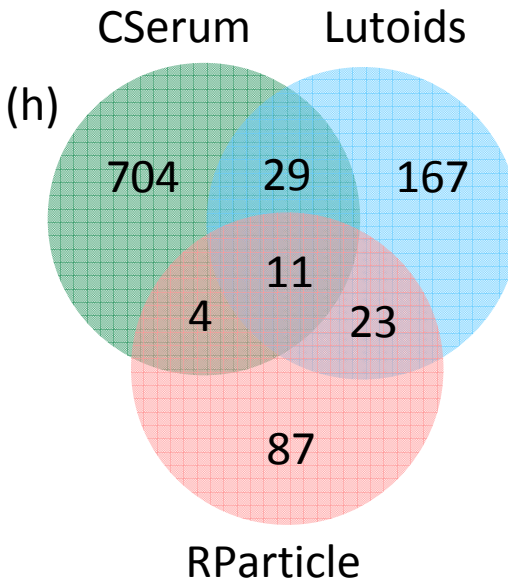

Figure 5 Venn diagrams of the numbers of protein and glycoprotein found in each subcellular fractions based on database: (a) photosynthesis, (b) latex allergens, (c) rubberwood formation, (d) latex biosynthesis, (e) disease resistance, (f) annHBM, (g) SwissProt, and (h) PlantGDB. (See Supplementary Tables $2 \mathrm{a}-2 \mathrm{~h}$ for the full list of proteins identified from each database). 


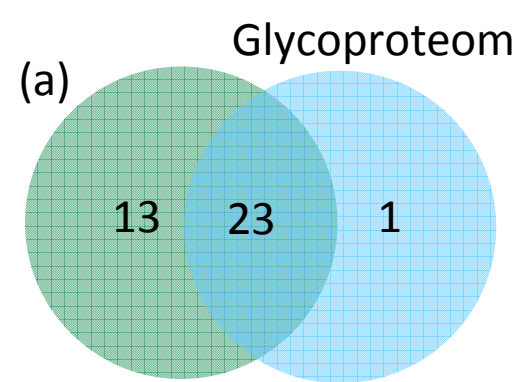

Proteomics (b)

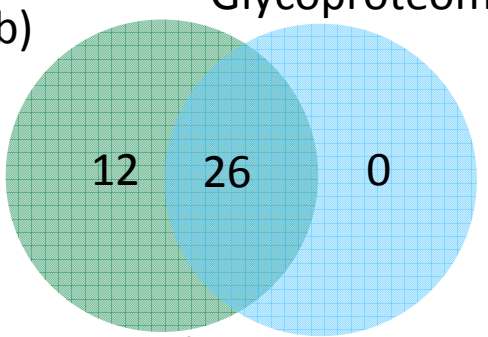

Proteomics (c)

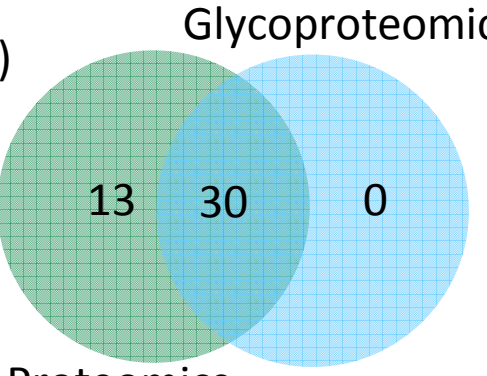

Proteomics (d)

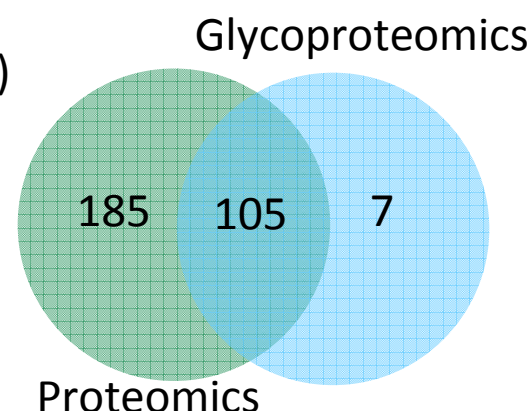

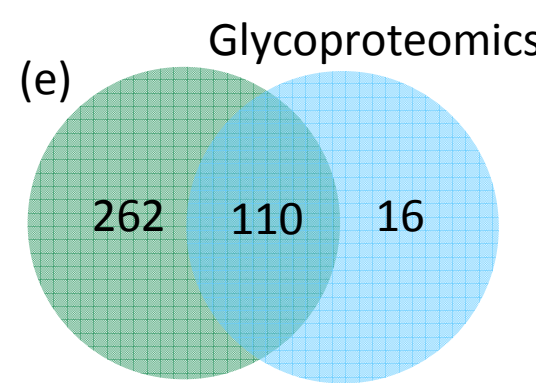

Proteomics

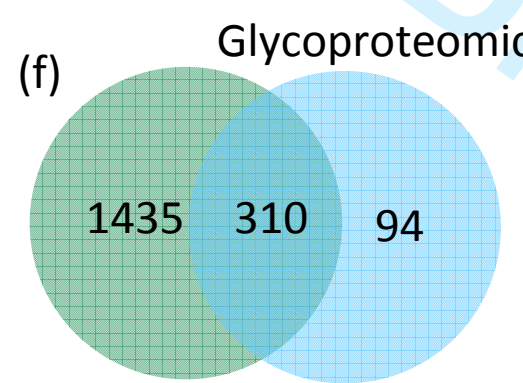

Proteomics

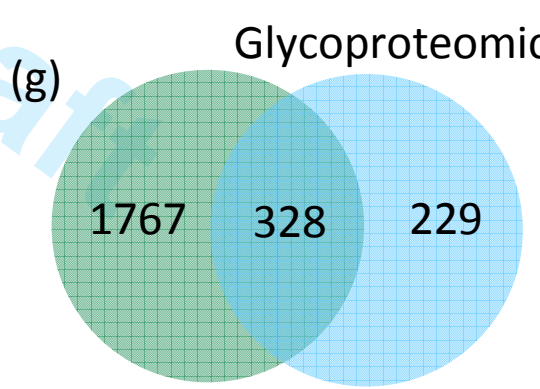

Proteomics (h)

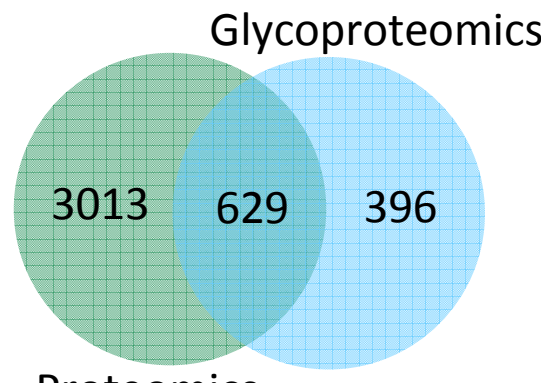

Proteomics

Figure 6 Venn diagrams of the numbers of protein and glycoproteins found in each extraction method based on database: (a) photosynthesis, (b) latex allergens, (c) rubberwood formation, (d) latex biosynthesis, (e) disease resistance, (f) annHBM, (g) SwissProt, and (h) PlantGDB. (See Supplementary Tables 3a$3 \mathrm{~h}$ for the full list of proteins identified from each database). 